\title{
Nanostructured $p$-Type Semiconductor Electrodes and Photoelectrochemistry of Their Reduction Processes
}

\author{
Matteo Bonomo and Danilo Dini * \\ Department of Chemistry, University of Rome "La Sapienza”, 00139 Rome, Italy; Matteo.bonomo@uniroma1.it \\ * Correspondence: danilo.dini@uniroma1.it; Tel.: +39-06-4991-3335
}

Academic Editor: Peter J. S. Foot

Received: 1 April 2016; Accepted: 6 May 2016; Published: 16 May 2016

\begin{abstract}
This review reports the properties of $p$-type semiconductors with nanostructured features employed as photocathodes in photoelectrochemical cells (PECs). Light absorption is crucial for the activation of the reduction processes occurring at the $p$-type electrode either in the pristine or in a modified/sensitized state. Beside thermodynamics, the kinetics of the electron transfer (ET) process from photocathode to a redox shuttle in the oxidized form are also crucial since the flow of electrons will take place correctly if the ET rate will overcome that one of recombination and trapping events which impede the charge separation produced by the absorption of light. Depending on the nature of the chromophore, i.e., if the semiconductor itself or the chemisorbed dye-sensitizer, different energy levels will be involved in the cathodic ET process. An analysis of the general properties and requirements of electrodic materials of $p$-type for being efficient photoelectrocatalysts of reduction processes in dye-sensitized solar cells (DSC) will be given. The working principle of $p$-type DSCs will be described and extended to other $p$-type PECs conceived and developed for the conversion of the solar radiation into chemical products of energetic/chemical interest like non fossil fuels or derivatives of carbon dioxide.
\end{abstract}

Keywords: semiconductor; photoelectrochemistry; $p$-type; reduction; dye-sensitized solar cell; solar fuels; $\mathrm{CO}_{2}$ reduction; metal oxides; metal chalcogenides

\section{Introduction}

The possibility of preparing nanostructured semiconductors of inorganic nature [1] in a controlled fashion allows the creation of systems with elevated chemical and physical stability which are endowed with open morphology and internal electrical transport. Such an achievement led to a rapid development of dye sensitized solar cells (DSCs) with efficiencies in the order of $10 \%$ [2-5], a value representing an impressive record if one takes into account that DSCs at their infancy in the late sixties displayed overall conversion efficiencies not exceeding 1\% [6]. In the nanoporous version inorganic semiconductors present a lower intrinsic conductivity with respect to their bulk counterparts, and lack the presence of an internal electric field due to the absence of a space charge layer due to charge separation [1]. Compared to bulk semiconductors, the relatively lower electrical conductivity of nanostructured semiconductors is mainly the consequence of frontier molecular orbitals which do not extend over the whole nanostructure thus impeding the delocalization of the electronic charge carriers [7]. Charge transport through such nanostructures occurs per percolation between sub-nanostructures and is based on the phenomenon of electron hopping between localized states with discrete energies [1]. Therefore, the localized states associated with shallow and deep traps as well as surface states, are particularly important in nanostructured semiconductors since both transport and the formation of the electrochemical double layer involve the occupation of such states with isolated energy levels [8]. At the morphological level the surface of nanostructured systems is mesoporous with pores sizes in the order of few nanometers (Figure 1) [9]. 


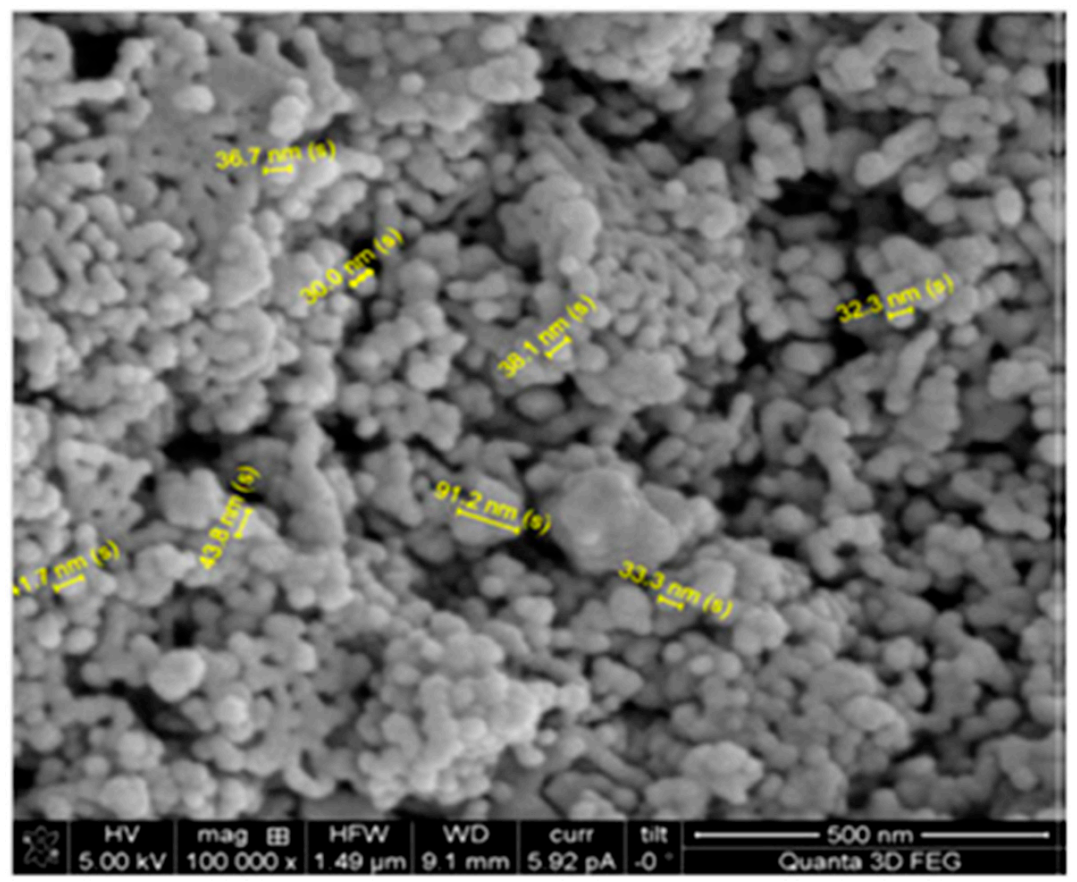

Figure 1. SEM image showing the mesoporous surface morphology of a nickel oxide cathode for DSC, which has been deposited via sintering of nanoparticles with diameter values comprised between 30 and $90 \mathrm{~nm}$ (evidenced in yellow). Reproduced with permission from reference [9].

This feature leads to a considerable increase (about 1000 times) of the surface area in comparison to compact surfaces, and, in case of nanostructured electrodes, this brings about also the corresponding increase of the contact area between the electrode and electrolyte. The latter fact will generally have very favourable effects on the kinetics of the processes of charge transfer that are localized on the surface of mesoporous electrodes as evidenced by the direct proportionality between the current density and electrode thickness in both dark conditions (Figure 2) [10] and under illumination (Figure 3) [11].

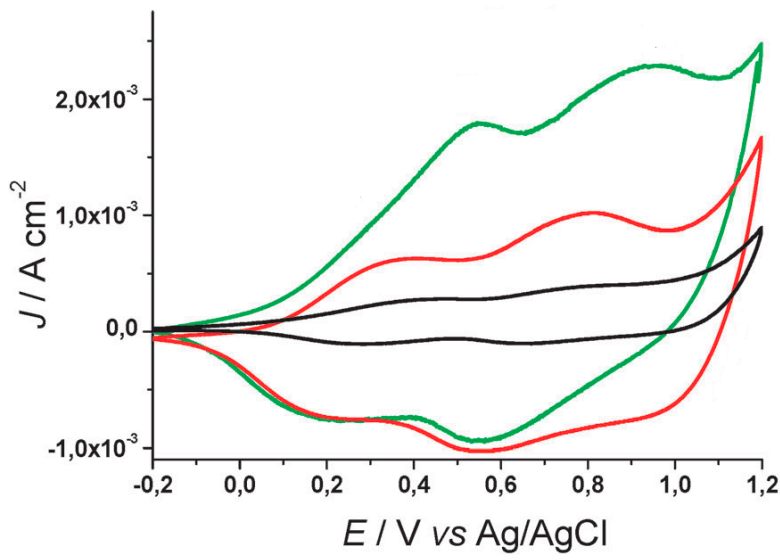

Figure 2. Cyclic voltammetries of mesoporous $\mathrm{NiO}$ cathodes at three different values of electrode thickness $l$. $J$ and $E$ represent the current density and the applied potential, respectively. Black trace: $l=0.4 \mu \mathrm{m}$; red trace: $l=1.8 \mu \mathrm{m}$; green trace: $l=2.7 \mu \mathrm{m}$. NiO is the electroactive species which undergoes the solid state redox processes $\mathrm{NiO}_{x}(\mathrm{OH})_{n}\left(\mathrm{H}_{2} \mathrm{O}\right)_{p} \rightarrow \mathrm{NiO}_{x}(\mathrm{OH})_{n+1}\left(\mathrm{H}_{2} \mathrm{O}\right)_{p-1}+e^{-}$ $+\mathrm{H}^{+}$for the oxidation peak recorded at lower electrical potential, and $\mathrm{NiO}_{x}(\mathrm{OH})_{n+1}\left(\mathrm{H}_{2} \mathrm{O}\right)_{p-1} \rightarrow$ $\mathrm{NiO}_{x}(\mathrm{OH})_{n+2}\left(\mathrm{H}_{2} \mathrm{O}\right)_{p-2}+e^{-}+\mathrm{H}^{+}$for the oxidation peak determined at higher electrical potential. Electrolyte: $0.2 \mathrm{M} \mathrm{KCl}, 0.01 \mathrm{M} \mathrm{KH}_{2} \mathrm{PO}_{4}$ and $0.01 \mathrm{M} \mathrm{K}_{2} \mathrm{HPO}_{4}$ in distilled water. Scan rate: $40 \mathrm{mV} \cdot \mathrm{s}^{-1}$. Adapted from reference [10]. 


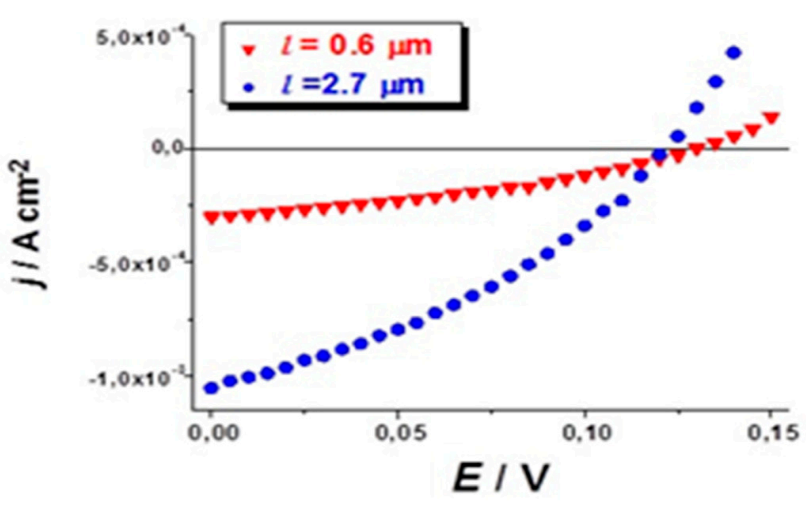

Figure 3. $j V$ characteristic curves of two $p$-DSCs differing for the thickness $(l)$ of the NiO photocathode. Sensitizer is erythrosine B. Electrolyte: $0.1 \mathrm{M} \mathrm{I}_{2}, 1.0 \mathrm{M} \mathrm{LiI}$ in acetonitrile. Incident light intensity: $1000 \mathrm{~W} \cdot \mathrm{m}^{-2}$. The radiation source is sun simulator with Air Mass 1.5. Photoelectrode electroactive area is $4 \times 4 \mathrm{~mm}^{2}$. Adapted from reference [11].

When nanostructured semiconductors are considered for $p$-type DSC ( $p$-DSCs) purposes [12], i.e., for PECs converting solar radiation into electricity with photoelectroactive cathodes (Figure 3), the thermodynamic condition to satisfy is the matching of the energy level of the redox couple with the upper edge of the valence band (VB) of the $p$-type electrode (Figure 4).

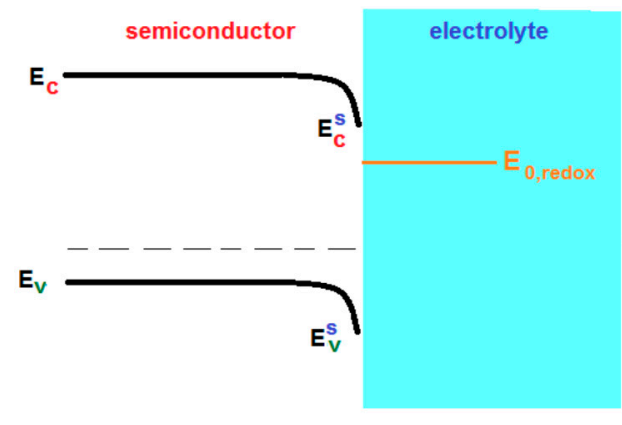

(a)

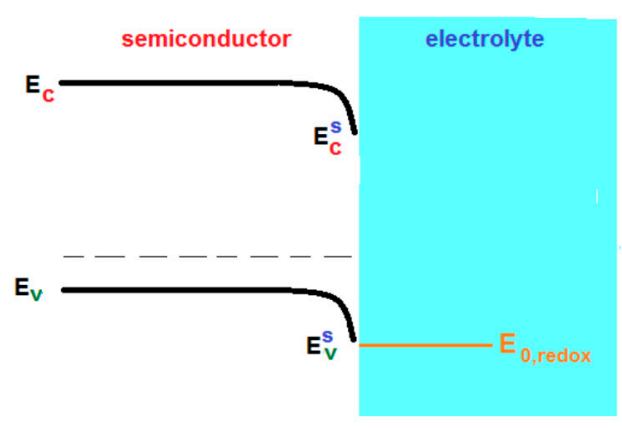

(b)

Figure 4. Position of the energy levels at the $p$-type semiconductor/electrolyte interface involved in the process of ET when a redox couple with energy level $\mathrm{E}_{0 \text {,redox }}$ is present in the electrolyte. The $p$-type electrode is reverse biased with consequent downward bending of the surface energy levels $E_{V}^{S}$ and $E_{C}^{s}$ with respect to the bulk levels $\mathrm{E}_{\mathrm{V}}$ and $\mathrm{E}_{\mathrm{C}}$. Lower scripts " $\mathrm{V}$ " and " $\mathrm{C}$ " refer to valence and conduction band, respectively. The dotted line represents the Fermi Energy level $E_{F}$. (a) Case of an ET process occurring from the conduction band (CB) of the $p$-type electrode to the oxidized form of the redox couple; (b) ET case occurring directly from the VB of the $p$-type electrode to the oxidized form of the redox couple.

The electrons representing the minority carriers of the $p$-type semiconductor, are transferred from the electrode to the oxidized form of the redox couple which, in turn, gets reduced with the passage of current upon promotion of electrons at energy levels superior to $E_{0, \text { redox }}$. Such a promotion of electrons to higher energy levels is induced by the luminous radiation that can be either directly absorbed by the nanoporous semiconductor (Figures 4 and 5) [13], or by a chemisorbed sensitizer with opportune positioning of the frontier energy levels with respect to the band edges of the semiconductor (Figure 6). The aspect of the large surface area in nanostructured semiconductors is particularly relevant in the ambit of DSCs in which the nanostructured electrodes are rendered photoelectrochemically active by chemisorbed dye-sensitizers. This is because the working principle of the DSCs requires the 
exploitation of large surface areas typical of mesoporous electrodes to anchor very large amounts of dye-sensitizers per unit geometrical area (typically in the order of $10^{-4}$ moles per cubic centimetre of porous semiconductor) [14]. Consequently, the parameter of APCE (absorbed photon-to-current conversion efficiency, Equation (1) [15]), in dyed mesoporous structures will reach much higher values with respect to sensitized compact semiconductors:

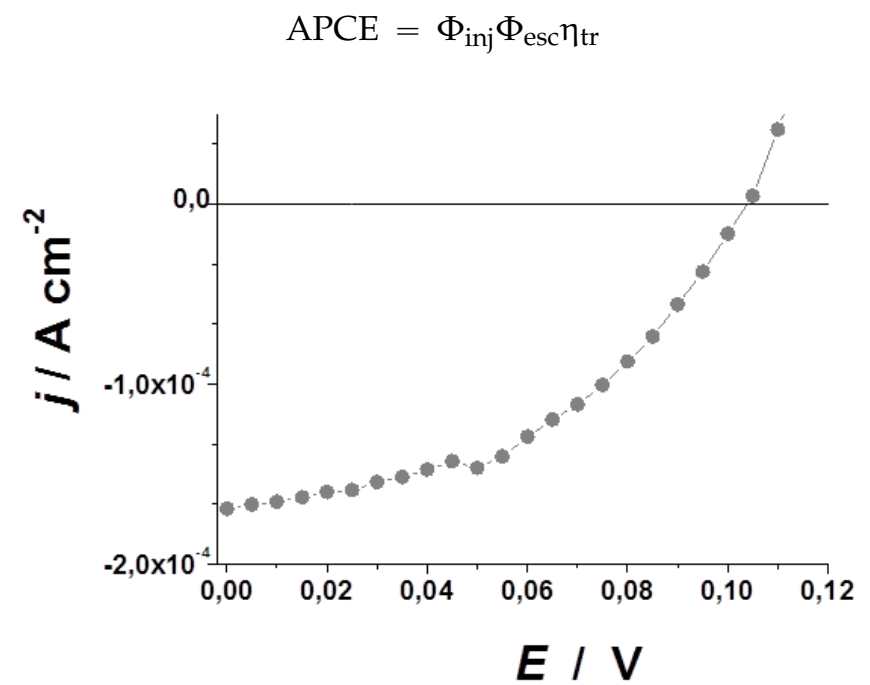

Figure 5. $j V$ characteristic curve of the $p$-DSC utilizing bare $\mathrm{NiO}$ photocathode, i.e., a sensitizer-free photoactive electrode. Electrolyte: HSE from Dyesol. Incident light intensity: $1000 \mathrm{~W} \cdot \mathrm{m}^{-2}$. The radiation source is sun simulator with AM 1.5G. The electroactive area of the photoelectrode is $5 \times 5 \mathrm{~mm}^{2}$. Adapted from reference [13].

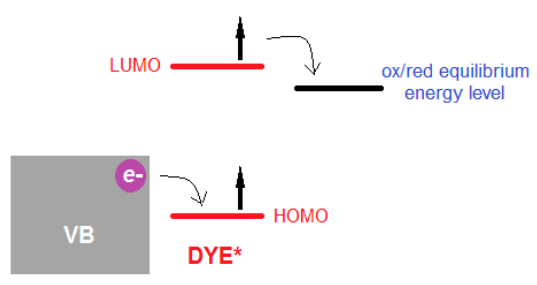

(a)
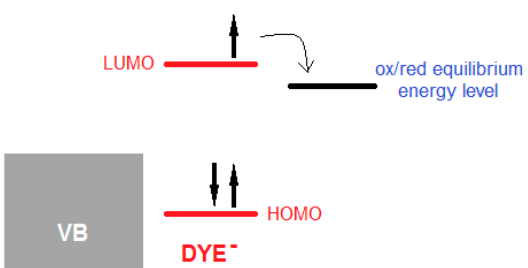

(b)

Figure 6. Mechanism of ET between the photoexcited dye sensitizer to the oxidized form of the redox mediator (with the redox energy level (in black) positioned below the LUMO of the dye-sensitizer) in a $p$-type sensitized cathode of a $p$-DSC. The relative positioning of the frontier energy levels involved in the photoreduction process is shown. (a): case of ET from the excited dye to the redox shuttle which precedes hole injection in the semiconductor VB (charge injection slower than ET); (b): case of ET from the excited dye to the redox shuttle which follows hole injection in the VB of the semiconductor (ET slower than charge injection). HOMO-LUMO energy separation for the immobilized sensitizer is assumed to be unvaried when the dye passes from the neutral state to (a) the oxidized or (b) the reduced state.

In Equation (1) $\Phi_{\text {inj }}, \Phi_{\text {esc }}$ and $\eta_{\text {tr }}$ represent the quantum yield of hole injection in the $p$-type semiconducting electrode, the probability with which the injected hole does not get recombined, and the efficiency of charge collection at $p$-type semiconductor/TCO interface, respectively. With the exception of the latter parameter $\eta_{\text {tr }}$ which depends basically on the intrinsic transport characteristics of the semiconductor, the first two terms $\Phi_{\text {inj }}$ and $\Phi_{\text {esc }}$ are directly related to the extent of surface area and express the probability that a hole photoinjected in the semiconducting electrode has to recombine either with the reduced dye, $\mathrm{D}^{-}$or with the reduced form of the redox pair, $\mathrm{S}^{-}$(Figure 6).

These two events of (unwanted) recombination occur on semiconductor surface and have rates $v_{\text {rec1 }}$ and $v_{\text {rec } 2}$ defined as follows: 


$$
\begin{gathered}
v_{\text {rec }, 1}=k_{\text {rec }, 1}\left[\mathrm{D}^{-}\right]\left[h^{+}\right]_{\text {surf }} \\
v_{\text {rec }, 2}=k_{\text {rec }, 2}\left[\mathrm{~S}^{-}\right]_{\text {surf }}\left[h^{+}\right]_{\text {surf }}
\end{gathered}
$$

Equations (2) and (3) show that $v_{\text {rec1 }}$ and $v_{\text {rec2 } 2}$ are directly proportional to the extent of surface area of the semiconductor/electrolyte interface through the terms of surface concentration of photoinjected holes $\left[h^{+}\right]_{\text {surf }}$, of reduced dye surface concentration $\left[\mathrm{D}^{-}\right]$, and of reduced shuttle surface concentration, $\left[\mathrm{S}^{-}\right]_{\text {surf. }}$. The rate constants $k_{\mathrm{rec}, 1}$ and $k_{\mathrm{rec}, 2}$ refer to the rates of recombination between photoinjected hole and reduced dye, and between photoinjected hole and reduced shuttle, respectively. It appears clear how fundamental is the fact that the photoinjected holes do have to diffuse away quickly from the site of their generation towards the bulk of the mesoporous structure and localize at a safe distance longer than that of tunneling with the frontier orbitals of the reduced dye (or the reduced form of redox shuttle), in order to preserve stably a high value of open circuit photovoltage, $V_{\mathrm{OC}}$ (Equation (4)), prior to any recombination:

$$
V_{\mathrm{OC}}=\left(k_{\mathrm{B}} T / e\right) \ln \left(n / n_{0}\right)
$$

In Equation (4) $n$ represents the concentration of free holes when the $p$-type semiconductor is illuminated, $n_{0}$ is the concentration of free holes in dark conditions (equilibrium value), $e$ is the elementary charge, and $k_{\mathrm{B}} T$ is the thermal energy at the given temperature $T$ [8]. Beside $V_{\mathrm{OC}}$, in DSCs the surface area of photoactive mesoporous semiconductors strongly affects also the other term of short-circuit photocurrent density, $j_{S C}(\lambda)$ being this one correlated to APCE (Equation (1)) through the relationship:

$$
j_{\text {SC }}(\lambda)=\operatorname{APCE}(\lambda) \cdot\left[1-10^{-\mathrm{A}(\lambda)}\right] \cdot e \cdot \Phi(\lambda)
$$

in which $A(\lambda)$ is the absorbance of the combination dye-semiconductor at the wavelength $\lambda$, and $\Phi(\lambda)$ is the flux of incident photons to the sensitized electrode per unit time and unit area at the wavelength $\lambda$. It is customary to justify the trend of the DSC photocurrent with the produced photovoltage to the equation of the photodiode (Equation (6)) [16], i.e., an illuminated $p-n$ junction, despite the electrochemical nature of the ET processes occurring in DSCs, which generally involve the formation of an electrochemical double layer with charge carriers of different nature, and phenomena of mass transport to allow the passage of an electrical current through the PECs [7,17]:

$$
j_{\text {photo }}=j_{\mathrm{SC}}-j_{\text {dark }}\left[\exp \left(e V / m \cdot k_{\mathrm{B}} T\right)-1\right]
$$

In Equation (6) $j_{\text {photo }}$ is the net photocurrent density, $j_{S C}$ is the short-circuit photocurrent density under illumination as defined in Equation (5), $j_{\text {dark }}$ is the dark current density, $m$ is the ideality factor of the diode, and $V$ is the voltage difference between the contacts. For a DSC based on photoactive nanostructured electrodes the term $j_{\text {photo }}$ defined in Equation (6) is related to the open circuit voltage of the DSC through the relationship [18]:

$$
j_{\text {photo }}=j_{\mathrm{SC}} \cdot\left\{1-\exp \left[e\left(V-V_{\mathrm{OC}}\right) / m k_{\mathrm{B}} T\right]\right\} /\left[1-\exp \left(-e V_{O C} / m k_{\mathrm{B}} T\right)\right]
$$

The general performance of the DSC is directly evaluated in terms of overall efficiency, $\eta$, which is, in turn, defined as the product of $j_{\mathrm{SC}}$ (Equation (5)) with $V_{\mathrm{OC}}$ (Equation (4)), and is defined as:

$$
\eta=j_{\mathrm{SC}} \cdot V_{\mathrm{OC}} \cdot \mathrm{FF} / I_{\mathrm{in}}
$$

In Equation (8) FF indicates the fill factor and $I_{\text {in }}$ the incident light intensity. Therefore, the three relevant parameters $\left(j_{\mathrm{SC}}, V_{\mathrm{OC}}, \mathrm{FF}\right)$ defining the overall efficiency (Equation (8)) are controlled by the mesoporous nature of the photoactive electrode (vide supra) in a light conversion device like the DSC [1,2]. In general, the performance of a DSC is dependent on many factors which include the nature of all materials employed in the DSC, size and geometry of the DSC, external electrical circuit, and device orientation with respect to light source. In particular, in the next section of the present review article the most recent developments on photoelectrochemically active cathodes [19] for $p$-DSCs [12] 
will be reported and analyzed. Successively the PECs utilizing photoelectrochemically active cathodes with nanostructured features for $\mathrm{H}_{2}$ production and $\mathrm{CO}_{2}$ reduction will be described briefly and reviewed considering above all those photoelectrochemical devices the working principle of which is the same of the Grätzel cell, i.e., the promotion of redox reaction(s) upon absorption of solar light by an opportune electron donor (the starting reductant). When realized through photoelectrolysis, both $\mathrm{H}_{2}$ fuel generation [20] and $\mathrm{CO}_{2}$ transformation [21] constitute redox reduction processes which occur at the photoactive cathodes exploiting the charge separation primarily induced by light absorption [22,23]. For this reason it will be shown in the last two sections of this contribution how important is the design of cathodes with photoelectrocatalytic properties, and how challenging is the eventual improvement of their photoelectrochemical performance via electrode and/or dye-sensitizer modification [24] to render feasible the production of energy by the renewable source of solar light.

\section{Cathodic Materials for $p$-DSCs}

It is well known that DSCs display the highest values of overall conversion efficiencies when employ photoactive $n$-type semiconductors like $\mathrm{TiO}_{2}$ or $\mathrm{ZnO}$ in the nanostructured version reaching values of overall efficiency comprised between $10 \%$ and $14 \%$ [4,5,25-27] Journal name]Volume:. In a successive phase of DSC development, several researchers have dedicated more attention towards the realization of tandem devices ( $t$-DSCs) $[12,28-31]$ which consider $n$ - and $p$-type nanostructured semiconductors respectively as photoanodes and photocathodes of the PEC. This cell configuration warrants the sure attainment of larger open circuit photovoltages with respect to the corresponding DSCs with single photoactive electrode being $V_{\mathrm{OC}}(t$-DSC $)=V_{\mathrm{OC}}(p$-DSC $)+V_{\mathrm{OC}}(n$-DSC $)$, with $V_{\mathrm{OC}}\left(p\right.$-DSC) and $V_{\mathrm{OC}}(n$-DSC) which indicate the open circuit voltage of the $p$-DSC with the same photocathode of the $t$-DSC combination, and the open circuit voltage of the $n$-DSC having the same photoanode of the $t$-DSC combination, respectively [32]. An important consequence of this specific property of $t$-DSCs is the total independence of the value of its open circuit voltage from the nature of the redox shuttle [7] being $V_{\mathrm{OC}}(t-\mathrm{DSC})=(1 / e)\left[\mathrm{E}_{\mathrm{V}}^{\mathrm{S}}\right.$ (cathode) $-\mathrm{E}_{\mathrm{C}}^{\mathrm{S}}$ (anode)] (Figure 7) [12]. Moreover, behind the development of increasingly efficient $p$-type materials for DSCs there is also the objective of achieving efficiencies theoretically larger than 1.5 times for $t$-DSCs with respect to those PECs employing only one photoactive electrode [32-34]. When DSCs are built up only with photoactive nanostructured cathodes, the corresponding performances are poorer with respect to the $n$-DSCs since the overall efficiencies of the $p$-DSCs are usually less than $10 \%$ of the same parameter determined with the best performing $n$-DSCs [35].

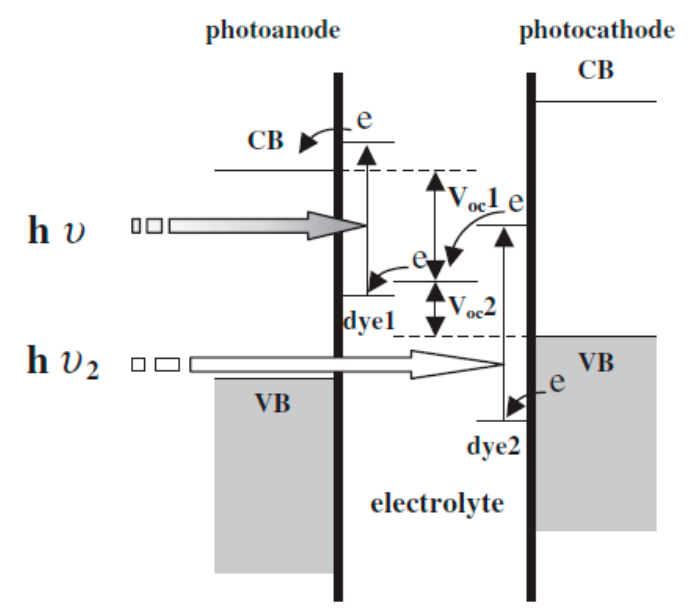

Figure 7. Principle of operation of a $t$-DSC in which the dye-sensitizers of the photoanode and the photocathode absorb light in different portion of the solar spectrum (feature of complementary absorption). Bent arrows indicate the displacement of the electrons from photocathode to photoanode within the cell as mediated by the dye-sensitizers in the light-induced excited state. Thick horizontal arrows indicate the different energies of the photons absorbed by the distinct sensitizers of the photocathode and photoanode. Reprinted with permission from reference [28]. 
This conspicuous difference of efficiencies between $n$ - and $p$-type devices appears now as the gap to overcome and the actual limiting factor for the realization of $t$-DSCs with improved performances in comparison to the DSC with single photoactive electrode [12]. By far, the most important cathodic material for $p$-DSC is nanostructured $\mathrm{NiO}[11,12,19,31,36-41]$ with which $p$-DSCs have reached a maximum of conversion efficiency of $2.55 \%$ when the electrolyte contained an iron-based redox shuttle [42], whereas the precedent record of $1.67 \%$ was achieved with a cobalt-based mediator [43]. All $p$-DSCs achieving more than $1 \%$ of overall conversion efficiency have insofar utilized the multifunctional dye PMI-6T-TPA [29] (Figure 8). The triad in question presents three distinct structural moieties which realize an equal number of diverse functions: (i) the two units of benzoic acid linked to the nitrogen of the amine, which represent the site of anchorage; (ii) the conjugated moiety consisting of the oligothiophene chain which acts as separator between the site of anchorage and the site of ET in order to prevent photoinjected charge recombination; (iii) the site of ET between the excited dye and the oxidized form of the redox mediator, which is the planar conjugated unit of perylene-monoimide.

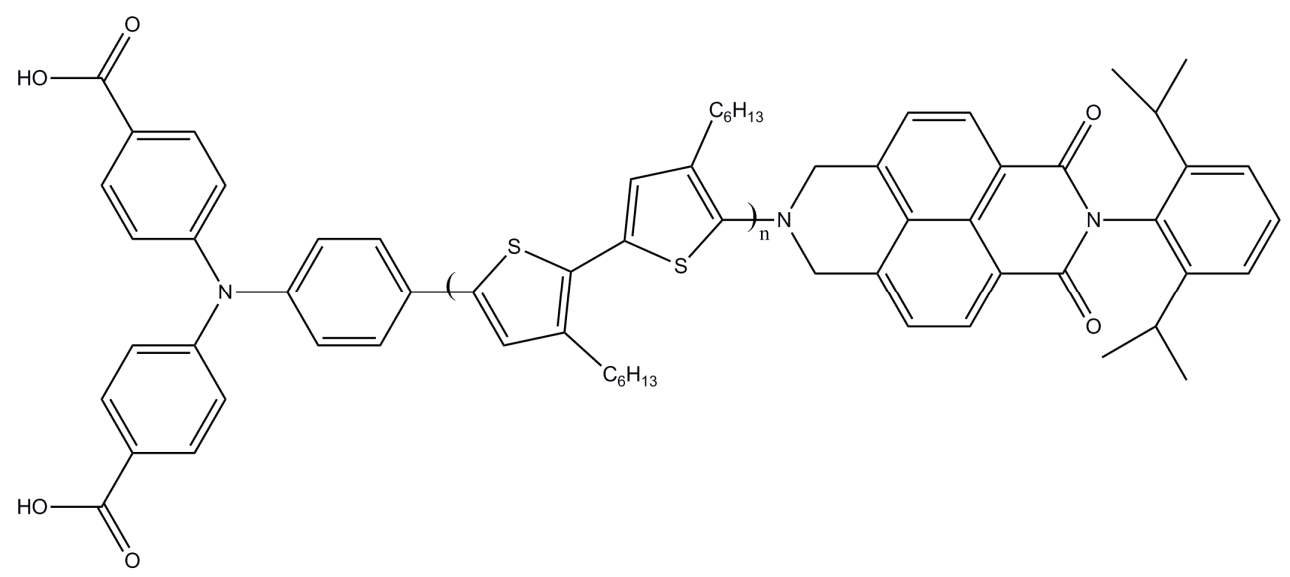

Figure 8. Structure of the molecule of PMI-6T-TPA representing the best performing dye-sensitizer for NiO-based $p$-DSCs [30].

The recent evolution of the records of efficiency registered for NiO-based $p$-DSCs is indicative of the importance of the nature of the electrolyte at this stage of development for devices like $p$-and $t$-DSCs (Figure 9) [44,45], but addresses also the issue of the need of further improving the characteristics of the nanostructured cathode.

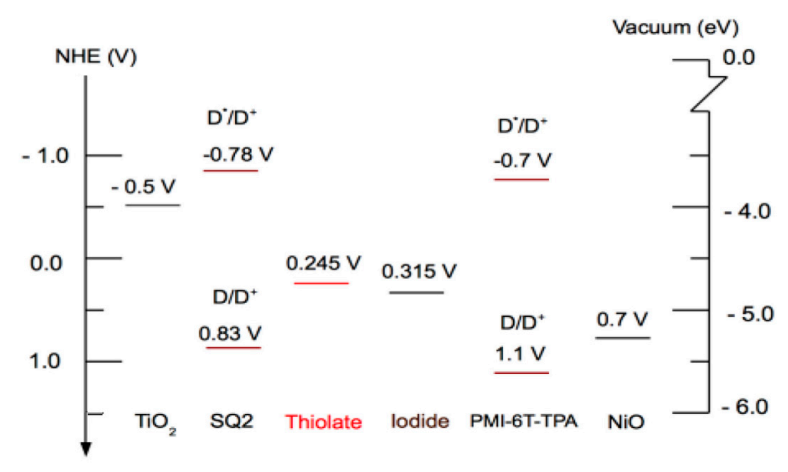

Figure 9. Potential and energy diagram for the components used in a $t$-DSC with $\mathrm{TiO}_{2}$ photoanode and $\mathrm{NiO}$ photocathode sensitized respectively with SQ2 [13] and PMI-6T-TPA. The rest potentials of iodide and thiolate based mediators are indicated. Adapted from reference [44].

It has been recently recognized that one of the most evident limits of $p$-DSCs based on $\mathrm{NiO}$ photoactive cathodes is the generally low value of fill factor FF which so far has never reached $45 \%[11,46]$. Several causes of this $\mathrm{NiO}$ specific behaviour have been addressed and recognized in 
the heavy recombination of photoinjected charges [47,48], intrinsic electrochromism of $\mathrm{NiO}$ in the nanostructured version [49], slow diffusion of photoinjected holes away from the site of generation at dye/ $\mathrm{NiO}$ interface [46], and in the capacitive character of $\mathrm{NiO}$ associated to the uptake of charge-compensating ions inside the oxide structure during the process of hole formation [7,49-51]. For this reason recently researchers have dedicated attention also to $p$-type semiconductors other than $\mathrm{NiO},[45,52-58]$ which possess the necessary features of nanostructured morphology and electrical connectivity between nanosized substructures. With the exception of potassium-doped zinc oxide $\left(\mathrm{K}_{x} \mathrm{ZnO}\right)$ [58], the other $p$-type photocathodic materials in question are all based on copper(I) oxide $\left(\mathrm{Cu}_{2} \mathrm{O}\right)$ [57] and the mixed oxides derivatives $\mathrm{CuAlO}_{2}$ [56], $\mathrm{CuGaO}_{2}$ [52-54] and $\mathrm{CuCrO}_{2}$ [45]. In Table 1 a comparison of the characteristic parameters of the $p$-DSCs differing for the nature of the nanostructured photocathode and colorant is given $[10,29,37,38,54,56,58-61]$. The sole parameter which is actually improved by replacing $\mathrm{NiO}$ with $\mathrm{CuAlO}_{2}$ or delafossite $\left(\mathrm{CuGaO}_{2}\right)$ is the open circuit voltage (Table 1) due to the lowering of the upper level of the $\mathrm{VB}$ in passing from $\mathrm{NiO}$ to $\mathrm{CuGaO}_{2}$ (Figure 10).

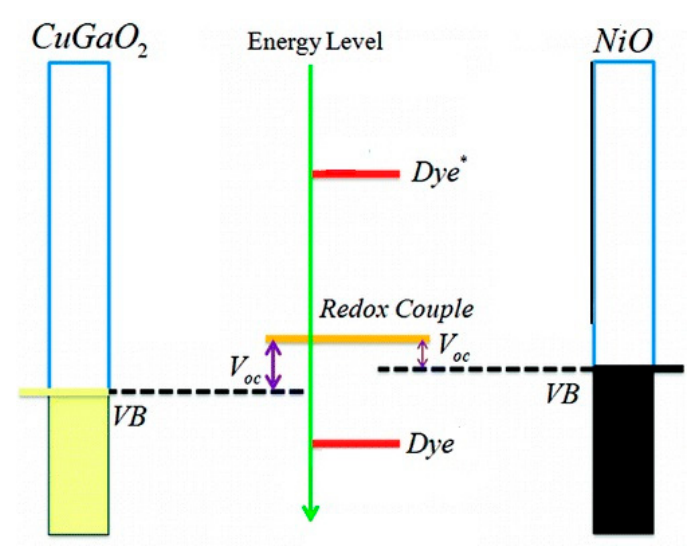

Figure 10. Potential energy diagram comparing the relative positions of the upper edge of the VB for $\mathrm{NiO}$ and $\mathrm{CuGaO}_{2}$ photocathodes sensitized with the same sensitizer (not specified). Upon adoption of the same redox mediator the amplitude of the open circuit voltage $V_{\mathrm{OC}}$ increases in passing from $\mathrm{NiO}$ to $\mathrm{CuGaO}_{2}$. Adapted from reference [53].

Table 1. Characteristic parameters of the $p$-DSCs differing for the nature of the nanostructured photocathode and dye-sensitizer. Redox shuttle: $\mathrm{I}_{3}{ }^{-} / \mathrm{I}^{-}$in acetonitrile.

\begin{tabular}{|c|c|c|c|c|c|c|}
\hline Cathode & Sensitizer & $\eta / \%$ & $V_{\mathrm{OC}} / \mathrm{mV}$ & $j_{\mathrm{SC}} / \mathrm{mA} \cdot \mathrm{cm}^{-2}$ & $F F / \%$ & Reference \\
\hline $\mathrm{NiO}-\mathrm{RDS}$ & P1 & 0.121 & 125 & -2.84 & 33.7 & [10] \\
\hline NiO-CS & P1 & 0.110 & 128 & -2.42 & 35.2 & [10] \\
\hline $\mathrm{NiO}$ sol-gel & P1 & 0.150 & 84 & -5.48 & 34.0 & [37] \\
\hline $\mathrm{NiO} \mu$-balls & PMI-6T-TPA & 0.460 & 208 & -6.36 & 34.0 & [38] \\
\hline NiO-NPs ${ }^{1}$ & PMI-6T-TPA & 0.410 & 218 & -5.35 & 35.0 & [29] \\
\hline $\mathrm{NiO} n$-rods ${ }^{2}$ & PMI-6T-TPA & 0.400 & 292 & -3.30 & 41.0 & [59] \\
\hline $\mathrm{CuAlO}_{2}$ & PMI-6T-TPA & 0.040 & 333 & -0.30 & 42.0 & [56] \\
\hline $\mathrm{NiO}$ sol-gel & PMI-NDI & 0.073 & 120 & -1.76 & 34.5 & [61] \\
\hline $\mathrm{CuGaO}_{2}$ & PMI-NDI & 0.023 & 187 & -0.29 & 41.0 & [54] \\
\hline $\mathrm{CuCrO}_{2}$ & C343 & 0.014 & 145 & -0.24 & 39.8 & [60] \\
\hline $\mathrm{K}_{x} \mathrm{ZnO}$ & C343 & 0.012 & 82 & -0.41 & 35.8 & [58] \\
\hline
\end{tabular}

${ }^{1}$ NPs: nanoparticles; ${ }^{2}$ n-rods: nanorods. 


\section{Photoelectrodes of $p$-Type for Non Fossil Fuel $\left(\mathrm{H}_{2}\right)$ Production}

Molecular hydrogen $\mathrm{H}_{2}$ represents the main non-fossil fuel the combustion of which does not pose any environmental issue in itself since the resulting product of oxidation would be water. Since $\mathrm{H}_{2}$ is attainable as the reduction product of $\mathrm{H}^{+}$cation it is then mandatory to focus the attention towards $p$-type electrodes having photoelectrocatalytic properties [62-64] towards the reduction of the proton either in the pristine state or with the surface modified by a dye-absorber/photocatalytic agent $[65,66]$. A comprehensive list of $p$-type semiconductor cathodes for the photoelectrochemical production of $\mathrm{H}_{2}$ has been given recently in [67] when the design of optimized photoelectrochemical water splitting cells $[68,69]$ was considered, and solar radiation represented the primary energy source for the activation of this conversion device [70]. One of the main concerns at the basis of the development of PECs for water splitting [71] which produce molecular $\mathrm{H}_{2}$ at the (photo)cathode and $\mathrm{O}_{2}$ at the (photo)anode is the replacement of precious metals like Pt or Ru photoelectrocatalysts with durable semiconducting electrodes of $p$-type based on cheaper metal oxides, phosphides and sulfides/disulfides or $\mathrm{Si}$, in order to photoactivate HER (hydrogen evolution reaction). Due to the wide employment in $p$-DSCs, $\mathrm{NiO}$ photocathodes have been considered also for the application of photoelectrochemical generation of $\mathrm{H}_{2}$ in a variety of sensitization schemes and surface decorations (Figures 11-14) [36,72-79].

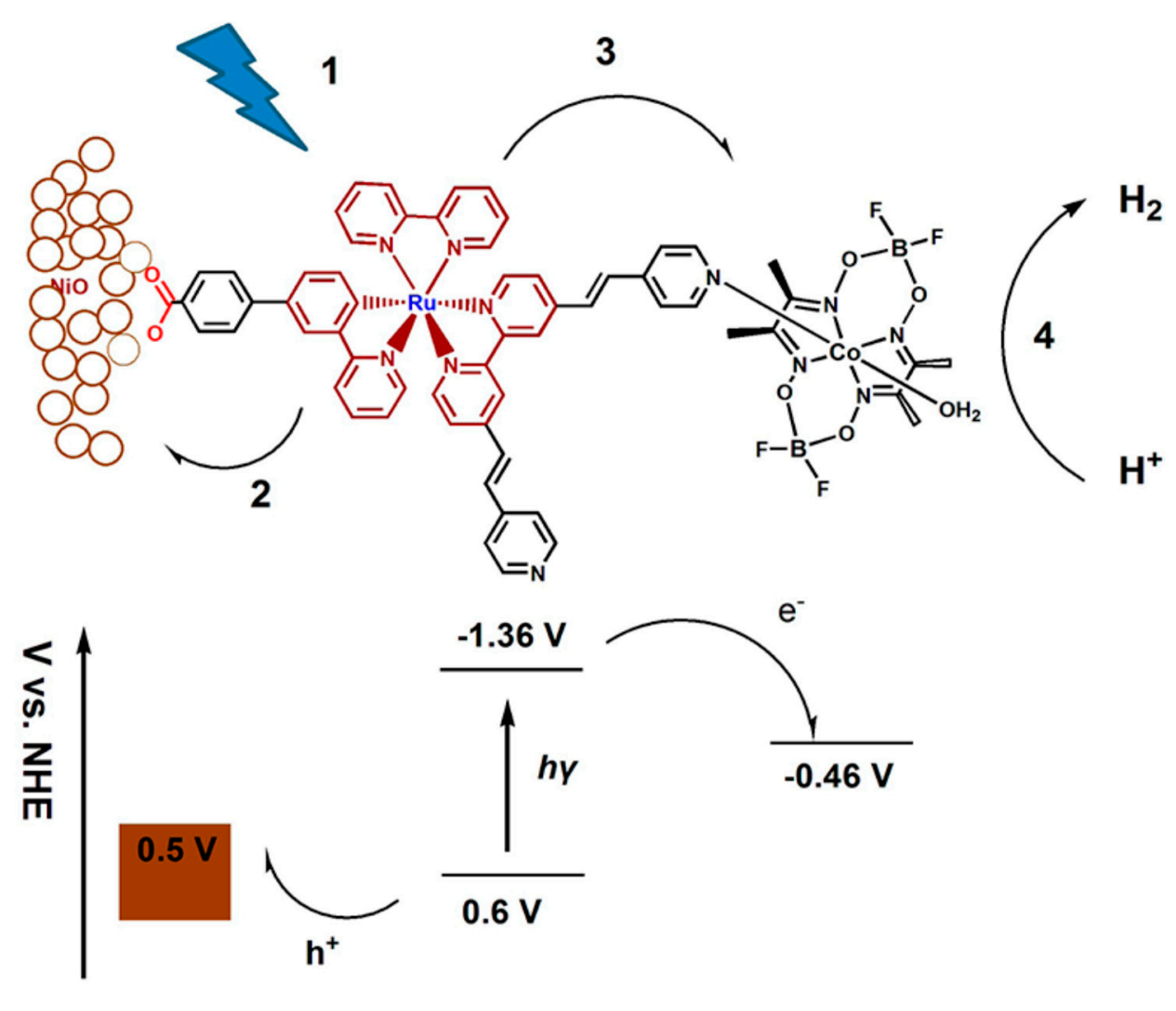

$\mathrm{NiO}$

022

CodmgBF $_{2}$

Figure 11. Energy diagram and scheme of the photoactivated overall process of ET from $\mathrm{NiO}$ to $\mathrm{H}^{+}$. The Ru-complex $\mathrm{O} 22$ immobilized on $\mathrm{NiO}$ surface is the dye-sensitizer acting as an electron donor towards the co-catalyst CodmgBF 2 , and as an electron acceptor from $\mathrm{NiO}$. The Co center of CodmgBF 2 complex is coordinated by a pendant pyridine group of O22. Reproduced with permission from reference [74]. 


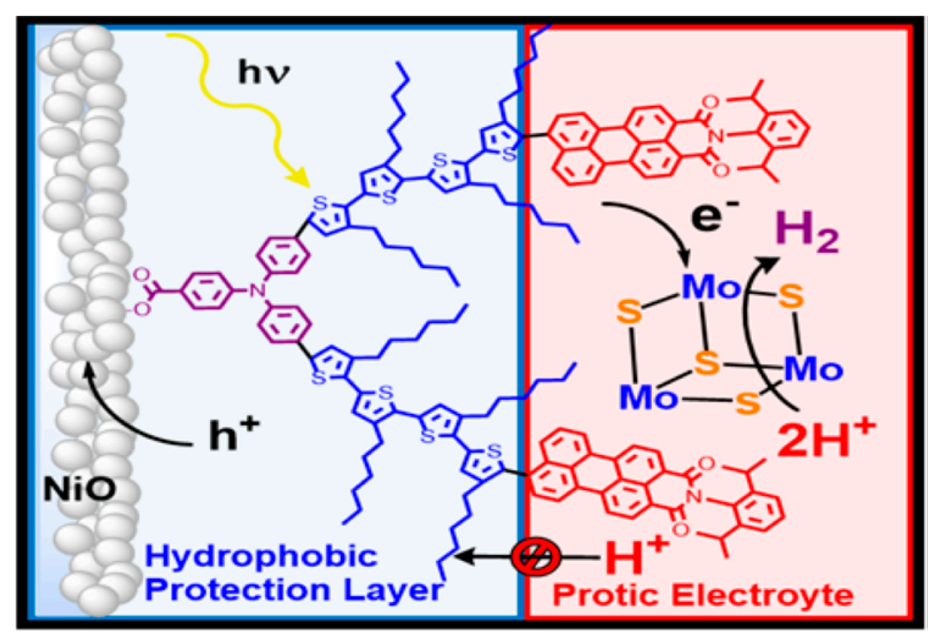

Figure 12. Scheme of photoactivated ET from $\mathrm{NiO}$ to $\mathrm{H}^{+}$mediated by the dye-sensitizer PMI-4T-TPA. The organic dye immobilized onto $\mathrm{NiO}$ surface is the dye-sensitizer which acts as electron donor towards the molecular co-catalyst $\mathrm{Mo}_{3} \mathrm{~S}_{4}$, and as an electron acceptor from $\mathrm{NiO}$. The picture evidences the blocking effect exerted by the hexyl groups against direct $\mathrm{H}^{+}$discharge onto bare $\mathrm{NiO}$ cathode (corresponding to a dark shunt effect). Reproduced with permission from reference [75].

Two main types of photocathode configuration have been identified with $\mathrm{NiO}$ surface being sensitized by a colorant (either organometallic (Figure 11) or organic (Figure 12)), which is electronically connected to the actual electrocatalyst of molecular hydrogen formation [74,75]. Another main typology of photocathode configuration is represented by the sensitization of $\mathrm{NiO}$ with quantum dots (QD) made of a second $p$-type semiconducting material with lowered VB edge with respect to $\mathrm{NiO}$, e.g., CdSe (Figures 13 and 14) [72,78]. Upon excitation of the QD this transfers an electron to the co-catalyst (usually a metal complex) and receives an electron from $\mathrm{NiO}$ in order to get regenerated for a successive cycle.
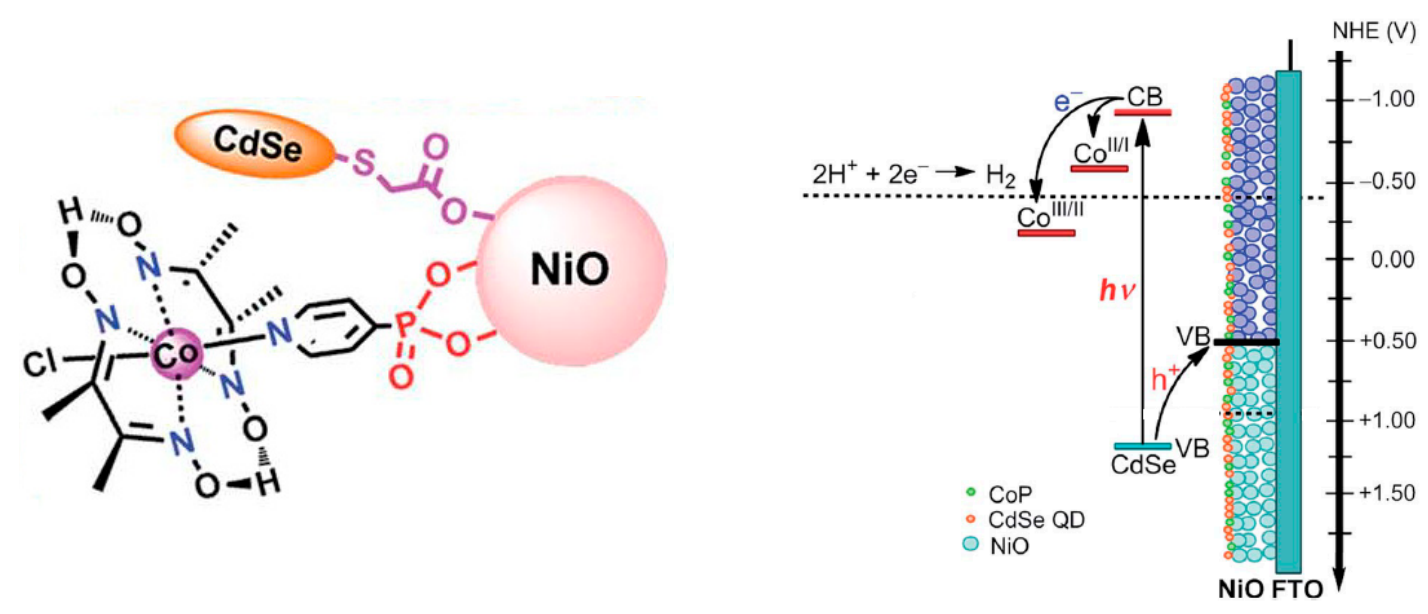

Figure 13. Left: depiction of the $\mathrm{NiO}$ photocathode sensitized by QD of CdSe and surface modified by the cobaloxime complex, i.e., the catalyst of molecular hydrogen formation. Right: potential levels involved in the process of light-induced ET from $\mathrm{NiO}$ to $\mathrm{H}^{+}$as mediated by QD sensitizer and Co catalyst. Adapted from reference [78]. 


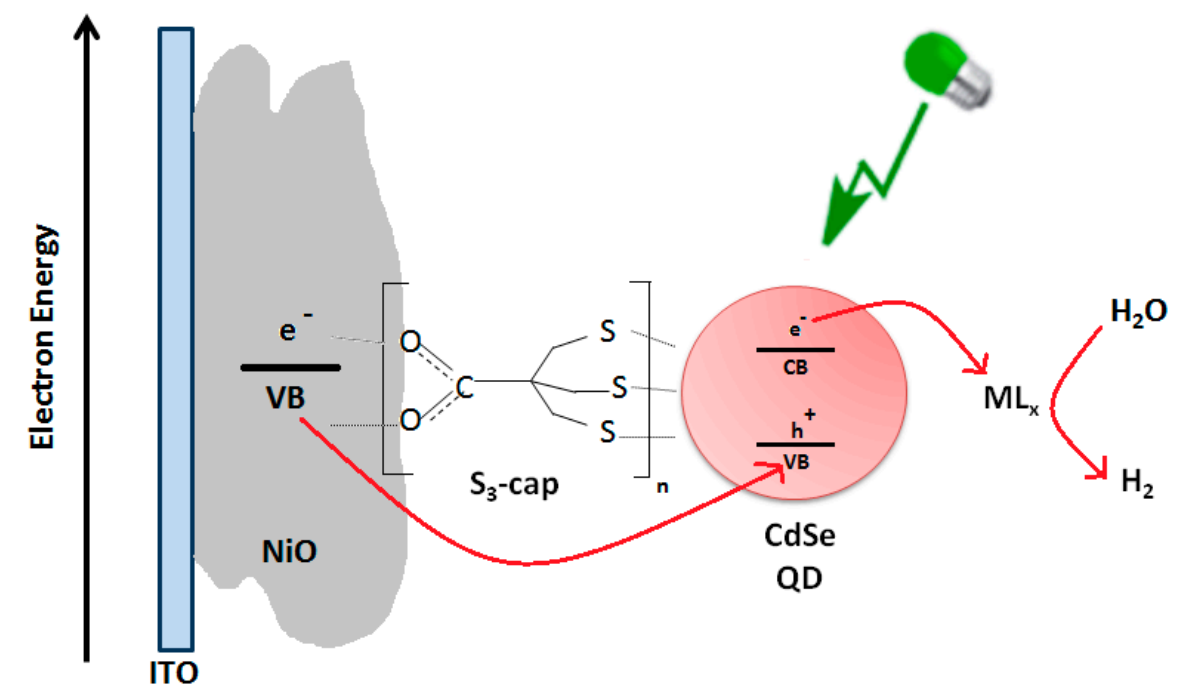

Figure 14. Scheme of the photoelectrochemical evolution of $\mathrm{H}_{2}$ using $\mathrm{S}_{3}$-cap-CdSe QD-sensitized $\mathrm{NiO}$ as photocathode. The complex $\mathrm{ML}_{x}$ indicates the catalyst forming molecular hydrogen $\left[\mathrm{Co}(1,2 \text {-benzenedithiolate })_{2}\right]^{-}$. Adapted from reference [72].

It is generally found that NiO-based photocatalysts for molecular hydrogen generation present almost quantitative faradic efficiency (an indication of the quasi total absence of photoelectrochemical and electrochemical side reactions), with turnover numbers (TONs) ranging in the broad interval $300-50,000$, and $\mathrm{H}_{2}$ formation rates in the order of few hundreds of nanomoles per hour. The cathodic overpotential of $\mathrm{H}_{2}$ generation can reach a maximum of $1.5 \mathrm{~V}$ vs. standard hydrogen electrode (SHE) with $\mathrm{NiO}$-based photocathodes. A recent comparative study on the photoelectrochemical performances of a series of differently prepared nanostructured $\mathrm{NiO}$ photocathodes [36] demonstrated that a direct correlation between photocurrent of $\mathrm{I}_{3}{ }^{-} / \mathrm{I}^{-}$-based $p$-DSC and photocurrent of $\mathrm{H}^{+}$reduction in the corresponding PEC does exist despite the different nature of the redox processes involved and, above all, the different sign of $\Delta \mathrm{G}$ for the two photoactivated reduction processes.

Another important series of photocathodes for $\mathrm{H}_{2}$ reduction is the one based on $p$-type $\mathrm{Cu}_{2} \mathrm{O}[62,66,80-86]$ for which several modes of surface modification have been considered to activate $\mathrm{H}^{+}$reduction. For example the decoration of copper(I) oxide with Pt nanoparticles and a protective layer of $\mathrm{TiO}_{2}$ [86] has led to the production of cathodic photocurrent densities $\left(j_{\mathrm{ph}, \mathrm{cat}}\right)$ in the order of $10 \mathrm{~mA} \cdot \mathrm{cm}^{-2}$ when photoelectrolysis was conducted in the potentiostatic mode at the applied potential of $0 \mathrm{~V}$ vs SHE. Replacement of Pt NPs with uniformly electrodeposited non-stoichiometric molybdenum sulphide $\left(\mathrm{MoS}_{2+x}\right)$ on AZO-modified $\mathrm{Cu}_{2} \mathrm{O}$ [81] led to a slight decrease of $j_{\text {ph,cat }}$ being approximately half of that achieved with Pt NPs decoration [86] at the same value of applied potential. An electrodeposit formed by a mixture of $\mathrm{MoS}_{2}$ and $\mathrm{MoS}_{3}$ onto $\mathrm{Cu}_{2} \mathrm{O}$ as well as a Ni-Mo catalytic alloy onto $\mathrm{Cu}_{2} \mathrm{O}$ have been considered as photoelectrocatalysts in strongly basic ambient $(1 \mathrm{M} \mathrm{KOH})$ for hydrogen photogeneration (Figure 15) [66]. In these conditions the value of $j_{\text {ph,cat }}\left(>6 \mathrm{~mA} \cdot \mathrm{cm}^{-2}\right)$ at the thermodynamic potential of $\mathrm{H}_{2}$ generation was very high in consideration of the fact that this value was achieved in basic conditions (Figure 15). Under these circumstances the formation rate of molecular hydrogen presented a maximum of about $30 \mu \mathrm{mol} \cdot \mathrm{h}^{-1}[66]$. 


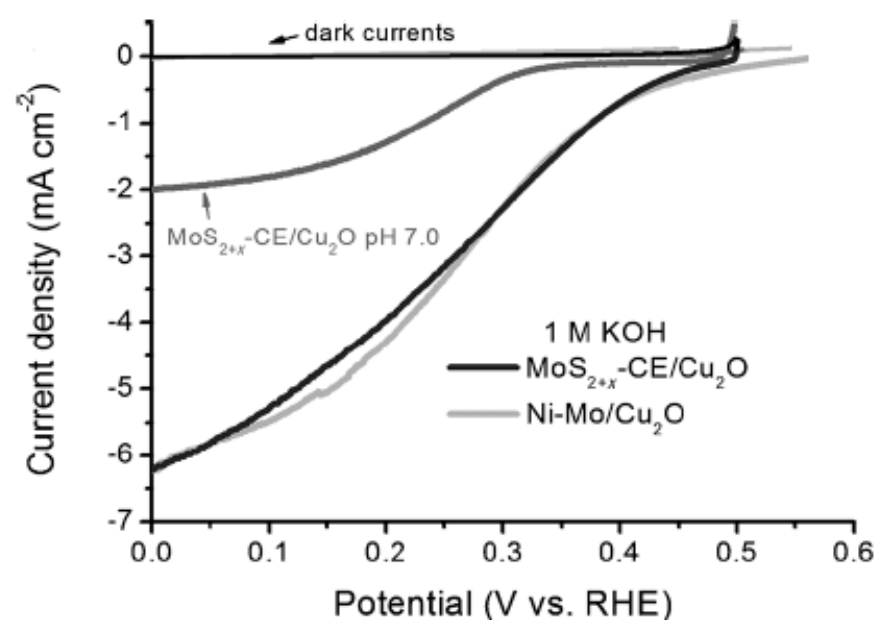

Figure 15. Profile of photocurrent-potential for cuprous oxide based photocathodes having a protected surface. Oxide surface was activated by the two different HER electrocatalysts Ni-Mo alloy and molybdenum sulfides. Adapted from reference [66].

$\mathrm{Cu}_{2} \mathrm{O}$ in the morphology of nanowires [83] was also decorated with $\mathrm{RuO}_{x}$ catalyst for $\mathrm{H}_{2}$ generation [62]. This system reached values of $j_{\text {ph,cat }}$ higher than $10 \mathrm{~mA} \cdot \mathrm{cm}^{-2}$ when the applied potential was $-0.3 \mathrm{~V}$ vs. SHE, and displayed IPCE larger than $70 \%$ in the wavelength range $400-500 \mathrm{~nm}$. The latter results was due to the higher optical absorbance of $\mathrm{Cu}_{2} \mathrm{O}$ in such an open morphology with respect to the compact thin film version [87]. Cuprous oxide has been also employed in heterostructures like $\mathrm{Cu}_{2} \mathrm{O} / \mathrm{RGO} / \mathrm{TiO}_{2}$ with $\mathrm{RGO}$ representing reduced graphene oxide [85], a system for which the rates of $\mathrm{H}_{2}$ production were particularly large (above $600 \mu \mathrm{mol} \cdot \mathrm{h}^{-1} \cdot \mathrm{m}^{-2}$ ) when the radiation intensity was only about $50 \mathrm{~mW} \cdot \mathrm{cm}^{-2}$. The inclusion of RGO had a favourable effect on the photocathode performance with respect to the simple heterojunction $\mathrm{Cu}_{2} \mathrm{O} / \mathrm{TiO}_{2}$ developed in precedence [80]. Some authors considered also the approach of surface etching for attaining an ameliorated photocathodic stability in cuprous oxide crystalline/polycrystalline electrodes [82]. In particular, it was stressed the fact that the nature of the crystallographic face of $\mathrm{Cu}_{2} \mathrm{O}$ actually exposed on the electrolyte controlled heavily the selectivity of the cathodic process with the (111) oriented face favouring the desired electrochemical process over copper oxide self-reduction to metallic $\mathrm{Cu}$. This was clearly demonstrated by a study which showed the dependence of the yield of HER on the index of $\mathrm{Cu}_{2} \mathrm{O}$ crystallographic plane of being the (111) face more active than the (110) [88]. Beside $\mathrm{NiO}[77,78,89]$ and $\mathrm{Cu}_{2} \mathrm{O}[90]$, other oxides [91-93] were studied as photocathodes for HER, e.g., the mixed oxides $p-\mathrm{CaFe}_{2} \mathrm{O}_{4}$ [94] and $p-\mathrm{LaFeO}_{3}$ with the latter system having presented an interesting value of hydrogen formation rate $\left(11.5 \mathrm{mmol} \cdot \mathrm{h}^{-1}\right)$ [95]. Metal sulfide photocathodes like $\operatorname{CoS}[96], \operatorname{CoS}_{2}$ [97,98], MoS [99,100], $\mathrm{MoS}_{2}$ [79,101-103], CoMoS $x$ [104], CdS [105,106], WS 2 [101], CuInS 2 [107] and metal phosphides ( $p$-InP [65,108,109], $p$-GaP [110], $p$-CoP [63]) have been also considered recently as photocathodes not containing noble metals or rare/expensive elements in PECs for photoactivated HER. Other groups of comparatively less studied photocathodic materials for HER have been the selenides of metals ( $\mathrm{CoSe}_{2}$ marcasite [68,111], NiSe ${ }_{2}$ [68], CdSe [72,79,105,106], MoSe [99]), nitrides of semi- and non-metallic atoms (GaN [112] and $\mathrm{C}_{3} \mathrm{~N}_{4}$ [113]), borides of metals $\left(\mathrm{Co}_{2} \mathrm{~B}\right.$ [114]), arsenides of semi-metallic atoms or non-metals (GaPNAs [115], GaAs [116], AlGaAs [116]), tellurides of metals (CdTe QD [73]), and carbides of semi-metallic atoms (4H-SiC [117], 3C-SiC [118]). From the thermodynamic standpoint photoactivated HER can take place provided that $p$-type photoelectrodes have a small bandgap with respect to the energy separation of water splitting levels, and the lower edge of CB is above the energy level of $\mathrm{H}^{+}$reduction (Figures 16 and 17) [98,119]. 


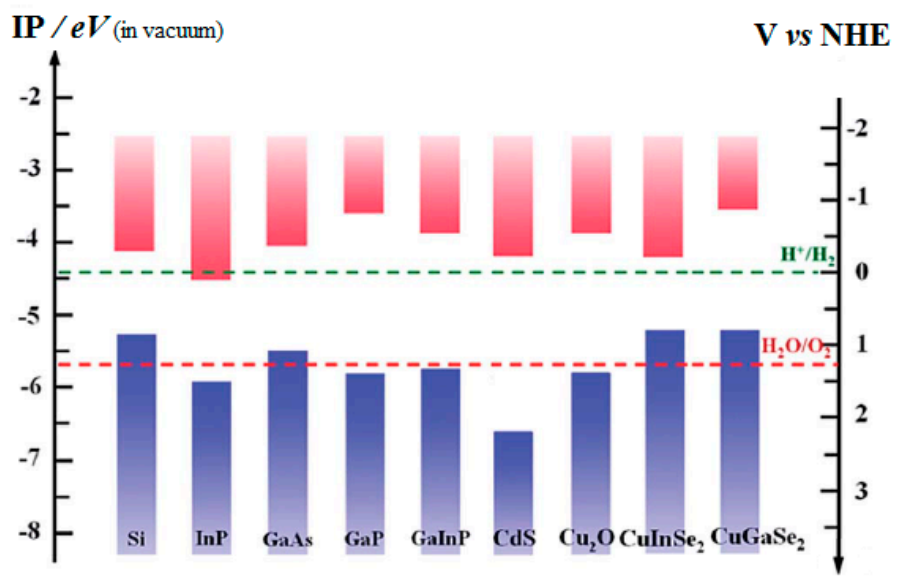

Figure 16. Positions of the band edges for some $p$-type semicondutors relative to the thermodynamic levels for water splitting. IP is the ionization potential energy evaluated with respect to the vacuum level. Adapted from reference [119].

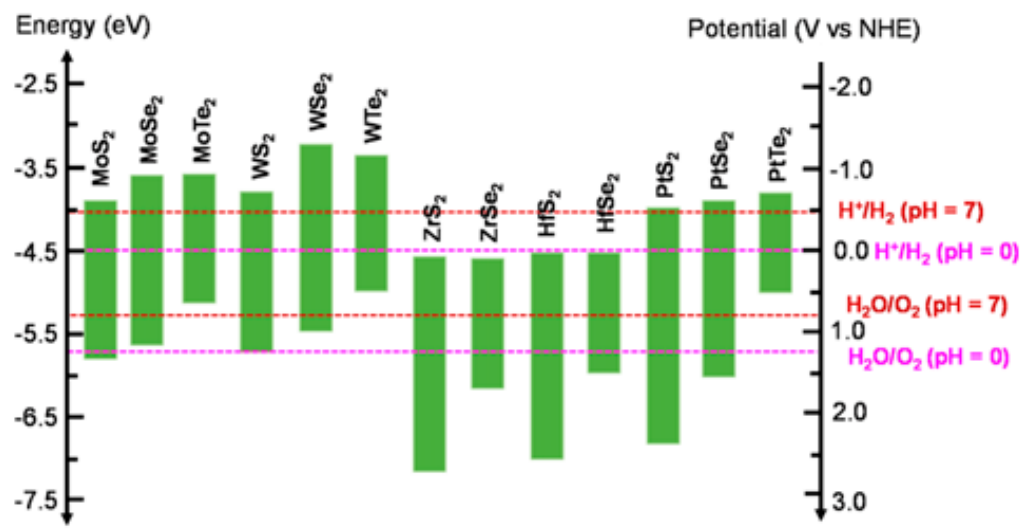

Figure 17. Positions of the band edges for some $p$-type sulfides, selenides and tellurides relative to the thermodynamic levels for water splitting at different $\mathrm{pH}$ values. Energy values on the left axis are relative to the vacuum level (equivalent to the zero energy level of the free electron). Adapted from reference [120].

The correlation between $j_{\mathrm{ph} \text {,cat }}$, overall solar energy-to- $\mathrm{H}_{2}(\mathrm{STH})$ conversion efficiency and photocathode bandgap is reported in Figure 18. This plot evidences the differences between $p$-type cuprous oxide, cadmium sulfide and copper gallium selenide, and shows the decrease of the overall efficiency of photoelectrochemical conversion upon increase of photocathode bandgap. This calculated trend is independent on the positions of the band edges of the three $p$-type photocathodes (Figure 16) [119]. 


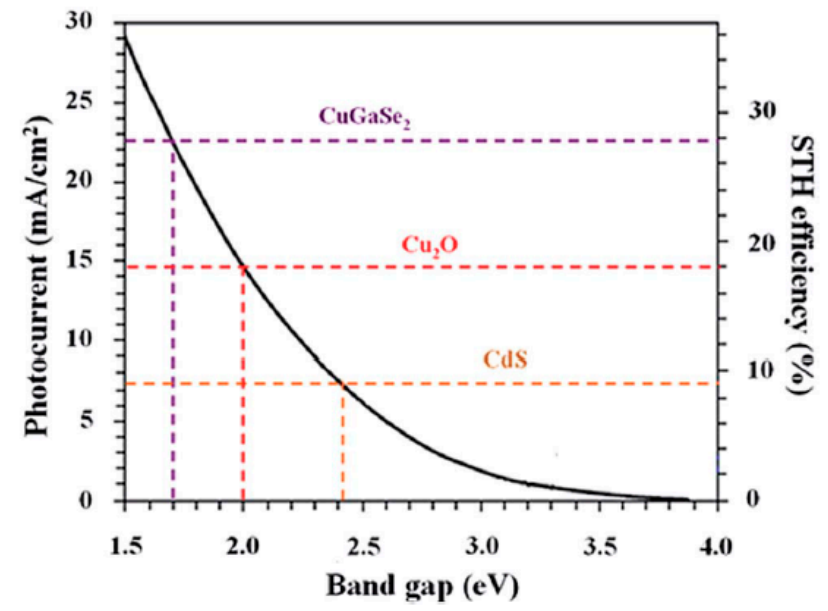

Figure 18. Dependence of the cathodic photocurrent density (left $Y$-axis), and overall conversion efficiency for the PEC mediated process of solar energy transformation into molecular hydrogen (STH, right $Y$-axis) on the value of energy bandgap of the photoelectroactive cathode. Reprinted with permission from reference [119].

A selection of the most relevant results recently achieved with water splitting photocathodes are presented in Tables 2 and 3 [121-123]. From these lists it emerges the superior performance of $p$-CuGaSe $e_{2}$ as photocathodic material for molecular hydrogen generation [122].

Table 2. Photocathodes, PECs details and electrochemical parameters of water photoelectrolysis for the production of $\mathrm{H}_{2}$. Illumination source is the solar simulator with $1.5 \mathrm{AM}$ spectrum. Data extracted from references [121-123] and references therein.

\begin{tabular}{cccc}
\hline Photocathode & $j_{\mathbf{p h}, \mathbf{c a t}} / \mathbf{m A} \cdot \mathbf{c m}^{-\mathbf{2}}$ & Applied poTential/V vs. SHE & Electrolyte \\
\hline$p-\mathrm{Cu}_{2} \mathrm{O}$ & 7.6 & 0 & $1 \mathrm{M} \mathrm{Na}_{2} \mathrm{SO}_{4}, \mathrm{pH}=4.9$ \\
$p-\mathrm{CuGaSe}_{2}$ & 20 & 0 & $0.1 \mathrm{M} \mathrm{Na}_{2} \mathrm{SO}_{4}, \mathrm{pH}=9$ \\
$p-\mathrm{CaFe}_{2} \mathrm{O}_{4}$ & 1 & -0.8 & $0.1 \mathrm{M} \mathrm{NaOH}$ \\
$p-\mathrm{Cu}_{2} \mathrm{ZnSnS}_{4}$ & 0.5 & 0 & $0.5 \mathrm{M} \mathrm{Na}_{2} \mathrm{SO}_{4}, \mathrm{pH}=6$ \\
$p$-CdSe QD on GDY & 0.07 & 0 & - \\
\hline
\end{tabular}

${ }^{1}$ V vs. Ag/ AgCl.

Table 3. Semiconducting electrodes, photoelectrocatalytic agents and conditions of photoelectrolysis for water splitting and $\mathrm{H}_{2}$ production.

\begin{tabular}{|c|c|c|c|c|}
\hline Photocathode & Catalyst & $j_{\mathrm{ph}, \mathrm{cat}} / \mathrm{mA} \cdot \mathrm{cm}^{-2}$ & Applied potential/V vs SHE & Reference \\
\hline $\mathrm{NiO}$ & $\mathrm{O} 22$ & 0.008 & 0.42 & [74] \\
\hline $\mathrm{NiO}$ & $\mathrm{O}_{22} / \mathrm{CodmgBF} 2$ & 0.019 & 0.46 & [74] \\
\hline $\mathrm{CaFe}_{2} \mathrm{O}_{4}$ & - & 0.16 & 0.92 & [94] \\
\hline $\mathrm{TiO}_{2}$ & SILAR CdS/CdSe & 6.0 & 0.5 & [106] \\
\hline $\mathrm{CuInS}_{2}$ & $\mathrm{Pt}$ & 5.2 & 0.28 & [107] \\
\hline $\mathrm{CuInS}_{2}$ & $\mathrm{Pt} / \mathrm{CdS}$ & 8.5 & 0.58 & [107] \\
\hline $\mathrm{CuInS}_{2}$ & $\mathrm{Pt} / \mathrm{TiO}_{2} / \mathrm{CdS}$ & 13 & 0.63 & [107] \\
\hline $\operatorname{InP}$ & - & 11 & 0.17 & [109] \\
\hline $\mathrm{InP}$ & $\mathrm{MoS}_{3}$ & 14.5 & 0.54 & [109] \\
\hline InP NWs & - & 14 & 0.49 & [109] \\
\hline InP NWs & $\mathrm{MoS}_{3}$ & 22 & 0.54 & [109] \\
\hline$p-\mathrm{GaP}$ & cobaloximeBF 2 & 1.2 & 0.64 & [110] \\
\hline$p-\mathrm{GaP}$ & cobaloximeH ${ }_{2}$ & 0.6 & 0.64 & [110] \\
\hline
\end{tabular}

In the case of disulfides (one of the most developed classes of materials in the recent past for photoelectrochemical molecular hydrogen production due to their inexpensiveness [105]) we report 
here the kinetic features associated to formation rates. For disulfides the rates of $\mathrm{H}_{2}$ formation are comprised between $0.1 \mathrm{mmol} \cdot \mathrm{h}^{-1}$ (case of the hybrid system $\mathrm{MoS}_{2} /$ graphene $/ \mathrm{TiO}_{2} \mathrm{NPs}$ ) to $1.3 \mathrm{mmol} \cdot \mathrm{h}^{-1}\left(\mathrm{MoS}_{2} /\right.$ graphene/CdS $)$ with quantum efficiencies (QE) ranging in the interval $9 \%-30 \%$ when radiation wavelength range is $350-450 \mathrm{~nm}$ [105]. These values are generally lower than those presented by metal-containing junctions like $\mathrm{Pt} / \mathrm{CdS}$ which gives typically formation rates close to $5 \mathrm{mmol} \mathrm{h}^{-1}$ and QE $\sim 50 \%$ at $420 \mathrm{~nm}$ [105]. When $\mathrm{MoS}_{2}$ is deposited onto $p$-Si the resulting photoelectrode gives $j_{\text {ph,cat }}=10 \mathrm{~mA} \cdot \mathrm{cm}^{-2}$ at $-0.187 \mathrm{~V} v$ s. SHE [105].

Molecular hydrogen can be photoelectrochemically generated also at the photocathodes obtained as a combination of a semiconducting material (not necessarily of $p$-type) with the graphene derivative RGO (reduced graphene oxide) [124]. Results of the photoelectrochemical performance achieved with PECs utilizing RGO-based photocathodes are reported in Table 4.

Table 4. Semiconducting materials combined with RGO as photocathodes of PECs generating $\mathrm{H}_{2}$. Illumination source is a Xe lamp with 1.5 AM spectrum. PECs, photoelectrolysis conditions and spectral conversion efficiencies are also reported. Data extracted from reference [123] and references therein.

\begin{tabular}{cccc}
\hline Photocathode & Applied Potential/V & Electrolyte & IPCE/\% \\
\hline $\mathrm{BiVO}_{4}$ & 0.75 vs. $\mathrm{Ag} / \mathrm{AgCl}$ & $\mathrm{Na}_{2} \mathrm{SO}_{4}$ & $4.2 @ 400 \mathrm{~nm}$ \\
$\mathrm{ZnO}$ & 0.4 vs. $\mathrm{Pt}(\mathrm{QRE})$ & $\mathrm{Na}_{2} \mathrm{SO}_{4}$ & $24 @ 400 \mathrm{~nm}$ \\
$\alpha-\mathrm{Fe}_{2} \mathrm{O}_{3} / \mathrm{BiV}_{1-x} \mathrm{Mo}_{x} \mathrm{O}_{4}$ & -0.04 vs. $\mathrm{Ag} / \mathrm{AgCl}$ & $\mathrm{Na}_{2} \mathrm{SO}_{4}$ & 0.53 \\
$\mathrm{Fe}_{2} \mathrm{O}_{3} / \mathrm{CNT}$ & 1.23 vs. $\mathrm{Ag} / \mathrm{AgCl}$ & $\mathrm{NaOH}$ & $7 @ 400 \mathrm{~nm}$ \\
$\alpha-\mathrm{Fe}_{2} \mathrm{O}_{3}$ & 0.5 vs. $\mathrm{Ag} / \mathrm{AgCl}$ & $\mathrm{NaOH}$ & $38 @ 400 \mathrm{~nm}$ \\
$\mathrm{Si}$ & -0.75 vs. $\mathrm{MSE}$ & $\mathrm{H}_{2} \mathrm{SO}_{4}, \mathrm{~K}_{2} \mathrm{SO}_{4}$ & - \\
$\mathrm{TiO}_{2}$ & 0.0 vs. Ag/AgCl & $\mathrm{Na}_{2} \mathrm{SO}_{4}$ & 0.05 \\
\hline
\end{tabular}

Finally, we report now on the photoelectrocatalytic activity of $p$-Si based photocathodes for HER when silicon has different morphologies (nanowires, micropyramidal, nanomesh), various degree of doping $\left(p-, n^{+}\right.$and $\left.n^{+} p p^{+}\right)$, and diverse types of photoelectrocatalyst (metallic, $p$-type semiconducting, metal alloy) [63,97,99,111,125-137]. A scheme of the energy levels involved in the interface $p$-Si/electrolyte for HER is given in Figure 19 [126]. Some recent data on the photoelectrocatalytic activity of $p$-Si based photocathodes for HER are listed in Table 5.

From the analysis of the data presented in Table 5, the factor which apparently most influences the photoelectrocatalytic performance of $p$-Si is its morphology. In fact, the systems possessing the most open morphologies, e.g., pyramids [99] or NWs [102], display the largest values of $j_{\text {ph,cat }}$ when $\mathrm{Si}$ is modified with Mo-based photocatalysts. In the framework of PECs with $p$-Si photocathodes for HER the most interesting finding is the comparable photoelectrochemical activity of these photoelectrodes when sensitized either with sulfide based semiconductors or with noble metals. The latter consideration indicates that the choice of the most appropriate combination semiconductor/photoelectrocatalyst for the future development of materials with photoelectrocatalytic activity towards $\mathrm{H}_{2}$ electrochemical formation should take into account at the same time not only the nature of the electro- and/or photo-active materials but also their morphology, surface extension, defectiveness, engineering of the junction interface(s) among other aspects. Once the full optimization of the photoelectrocatalytic junction for HER has been achieved in terms of materials choice, the attention of the researcher should be directed towards the most general issues of durability, chemical stability, robustness, thermal stability, cost/effectiveness ratio, device engineering, PEC design, reliability and reproducibility of the solar conversion device to render practically feasible both at an economic and chimico-physical levels the concept of sun driven photoelectrolysis of water as far as the aspect of non-fossil fuel production is concerned [138-148]. 


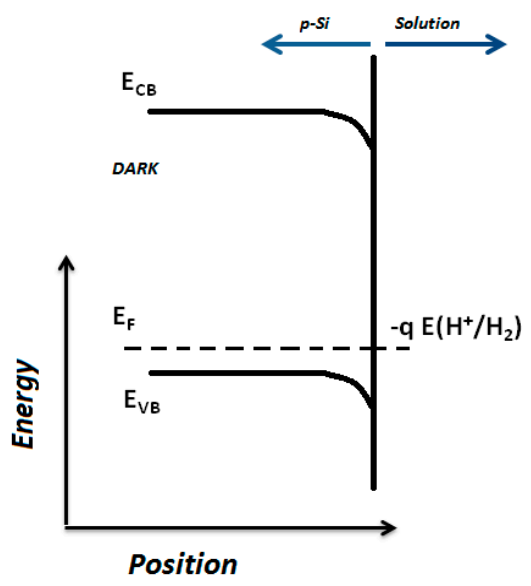

(a)

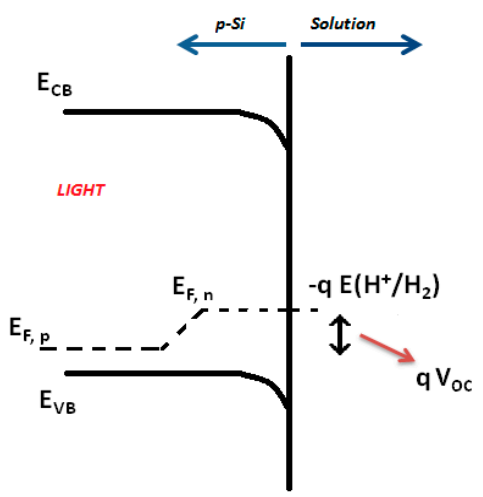

(b)

Figure 19. Bending of the energy levels at the interface $p$-Si/electrolyte in presence of the redox couple $\mathrm{H}^{+} / \mathrm{H}_{2}$ at the redox potential $\mathrm{E}\left(\mathrm{H}^{+} / \mathrm{H}_{2}\right)$. The depiction is given in both dark conditions $(\mathbf{a})$, and under illumination (b). $\mathrm{E}_{\mathrm{F}}$ represents the Fermi level of $p$-Si semiconductor. Symbols $\mathrm{E}_{\mathrm{F}, p}$ and $\mathrm{E}_{\mathrm{F}, n}$ refer to the quasi Fermi levels of the holes and electrons, respectively, when the interface is under illumination. Adapted from reference [126].

Table 5. Si based $p$-type semiconducting electrodes, photoelectrocatalytic agents and conditions of photoelectrolysis for $\mathrm{H}_{2}$ production from water splitting.

\begin{tabular}{|c|c|c|c|c|}
\hline Photocathode & Catalyst & $j_{\mathrm{ph}, \mathrm{cat}} / \mathrm{mA} \cdot \mathrm{cm}^{-2}$ & Applied Potential/V vs. SHE & Reference \\
\hline$p-\mathrm{Si}$ & Au NF & 24.5 & 0.14 & [130] \\
\hline$p-\mathrm{Si}$ & $\mathrm{Pt} / \mathrm{Au} \mathrm{NF}$ & 24.4 & 0.25 & [130] \\
\hline$p$-Si & $a-\operatorname{CoMoS}_{\mathrm{x}}$ & 17.5 & 0.25 & {$[97]$} \\
\hline$p$-Si & $a-M_{0} S_{x}$ & 6.0 & 0.20 & [97] \\
\hline$n^{+} p-\mathrm{Si}$ & $\mathrm{CoP}$ & 20 & 0.47 & [63] \\
\hline Si $\mu$-py & $\mathrm{MoS}_{\mathrm{x}} \mathrm{Cl}_{\mathrm{y}}$ & 43.0 & 0.41 & [99] \\
\hline Si $\mu$-py & $\mathrm{MoSe}_{\mathrm{x}} \mathrm{Cl}_{\mathrm{y}}$ & 38.8 & 0.35 & [99] \\
\hline$p$-Si & $\mathrm{CoSe}_{2}$ & 9.0 & 0.18 & [111] \\
\hline Si NWs & ELD Pt & 23 & 0.28 & [131] \\
\hline$p$-Si & $\mathrm{Ti} / \mathrm{Ni}$ & 5 & 0.30 & [132] \\
\hline$a-S i$ & $\mathrm{Pt}$ & 4.5 & $-0.5^{1}$ & [133] \\
\hline$n^{+} p p^{+}-\mathrm{Si} \mathrm{NM}$ & $\mathrm{Pt}$ & 8.2 & 0.25 & [134] \\
\hline$n^{+} p p^{+}-\mathrm{Si} \mathrm{NW}$ & $\mathrm{Pt}$ & 4.9 & 0.25 & [134] \\
\hline$p-\mathrm{Si}$ & $\mathrm{Ni}$ & 13.5 & $0.35^{2}$ & [135] \\
\hline$p-S i$ & $\mathrm{Pt}$ & 21.5 & $0.27^{2}$ & [135] \\
\hline$n^{+} p-\mathrm{Si}$ & $\mathrm{Pt}$ & 28 & 0.56 & [126] \\
\hline$n^{+} p$-Si wires & $\mathrm{Pt}$ & 15 & 0.54 & [126] \\
\hline$p$-Si & $\mathrm{MoS}_{2}$ & 8.5 & 0.23 & [103] \\
\hline$p$-Si NWs & $\mathrm{MoS}_{2}$ & 18 & 0.31 & [102] \\
\hline$p$-Si NWs & $\mathrm{Pt}$ & 15 & 0.37 & [102] \\
\hline$p$-Si $\mu \mathrm{Ws}$ & $\mathrm{CoS}_{2}$ & 3.2 & 0.25 & [97] \\
\hline$p$-Si NWs & $\mathrm{Pt}$ & 17 & 0.42 & [97] \\
\hline
\end{tabular}

${ }^{1} \mathrm{~V}$ vs. $\mathrm{RuO}_{2} \mathrm{QRE}^{2} \mathrm{~V}$ vs. SCE.

\section{4. $p$-Type Photoelectrodes for Carbon Dioxide Photoelectrochemical Reduction}

Carbon dioxide $\mathrm{CO}_{2}$ is the major combustion product present in the terrestrial atmosphere, and is produced by anthropical activity at a rate of about $10^{10}$ tons per year [149] mainly as the consequence of the production of mechanical, electrical and thermal energy via coal, gas and oil combustion. For several important reasons like climate change impact and the challenging undertake of the correlated initiatives [150], a re-utilization of the $\mathrm{CO}_{2}$ derived from exhaust via a renewable source of energy like the solar radiation, would really constitute an invaluable achievement for mankind and its preservation. Among the various strategies of $\mathrm{CO}_{2}$ transformation the one based on the 
photoelectrochemical reduction of carbon dioxide is one of the most sought after for a full employment on long term basis since it would realize the reconversion of carbon dioxide into high-density energy fuels like methane, methanol, or into chemicals in use for organic syntheses and polymer chemistry, upon activation of an electrolytic cell with sunlight. For these photoelectrolytic processes theoretical efficiencies are expected to fall in the range $20 \%-40 \%$ [149]. Ideally, the corresponding photoelectrochemical plant should lead to the recycling of $\mathrm{CO}_{2}$ to diminish the consumption of fossil fuels. For the redox reduction of $\mathrm{CO}_{2}$ photoelectrochemistry/photovoltaics can be exploited through two principal approaches: (i) the photoelectrochemical production of $\mathrm{H}_{2}$ followed by its chemical combination with $\mathrm{CO}_{2}$ to give selectively $\mathrm{CH}_{3} \mathrm{OH}$; (ii) the direct photoelectrochemical reduction of $\mathrm{CO}_{2}$. The photoactivated electron reduction of $\mathrm{CO}_{2}$ according to strategy (ii) seems the most walkable route in terms of feasibility and costs in comparison to strategy (i) since the latter requires collection and storage of the gaseous reactant $\mathrm{H}_{2}$, a species which is generally produced at too low pressures of operation with respect to what required by the large scale transformation of $\mathrm{CO}_{2}$ [149].

The direct conversion of carbon dioxide $\left(\mathrm{CO}_{2}\right)$ into the closest reduction product carbon monoxide (CO) involves the breaking of the $\mathrm{C}=\mathrm{O}$ double bond. Such a process requires the absorption of $187 \mathrm{kcal} \cdot \mathrm{mol}^{-1}$, i.e., an amount of energy which is equivalent to approximately $8 \mathrm{eV}$ and corresponds to a radiation wavelength of $150 \mathrm{~nm}$. This consideration clearly indicates that visible light (wavelength range: $400-700 \mathrm{~nm}$ ) does not carry sufficiently high energy to induce the photochemical reaction $\mathrm{CO}_{2} \rightarrow$ $\mathrm{CO}+$ subproducts. Analogous considerations in terms of energetics can be made for the transformation of $\mathrm{CO}_{2}$ into other reduction products like $\mathrm{CH}_{2} \mathrm{O}, \mathrm{CH}_{3} \mathrm{OH}$ or $\mathrm{CH}_{4}$ which are obtained by the breaking of one $\mathrm{CO}$ bond of carbon dioxide molecule. The activation energy for the reduction of $\mathrm{CO}_{2}$ reduces approximately to half $\left(95 \mathrm{kcal} \cdot \mathrm{mol}^{-1}\right)$ when formate, oxalate and their acidic forms are the reduction products of carbon dioxide since their formation does not require the elimination of one oxygen atom from the starting material $\mathrm{CO}_{2}$ but only the breaking of $\pi$-bonds between carbon and oxygen atoms. The light induced activation of this second series of processes would require now the absorption of UV radiation at about $300 \mathrm{~nm}(4 \mathrm{eV})$. Moreover, if the activation of $\mathrm{CO}_{2}$ is achieved through the addition of one electron with consequent formation of the radical anion $\mathrm{CO}_{2}{ }^{-}$, even visible light can be useful since the mono-electronic reduction potential of carbon dioxide is $-1.9 \mathrm{~V}$ (vs. SHE) [151], which corresponds to the radiation wavelength of $630 \mathrm{~nm}$. Therefore, red light would be sufficient to promote the insertion of one electron into the LUMO of $\mathrm{CO}_{2}$ provided that an appropriate light-absorbing reducing agent, either molecular or structured, is available at a tunnelling distance from $\mathrm{CO}_{2}$. The activation of carbon dioxide via mono- or multi-electron [152] reduction can be carried out in three different ways: (i) chemically, by means of molecular or structured catalysts as electron donating species that coordinate $\mathrm{CO}_{2}$ efficiently (the process can be either homogeneous or heterogeneous) [153]; (ii) electrochemically, in which $\mathrm{CO}_{2}$ is reduced at the cathode surface of an electrochemical cell (typically heterogeneous process) via electrode polarization at an opportune potential value which is system specific [154-157]; (iii) electrocatalytically, where the cathodes of the electrochemical cell are modified by a molecular catalyst either anchored on the cathode or dissolved in the electrolyte $[158,159]$, with the aim of decreasing the activation energy of the electrochemical reduction of $\mathrm{CO}_{2}$. The strong nucleophilic character of the resulting reduction product $\mathrm{CO}_{2}{ }^{-}[160]$, renders it an attractive species which bears great synthetic importance since it can form organic compounds of interest upon combination with appropriate electrophilic substrates [161,162]. As previously introduced, reducing $\mathrm{CO}_{2}$ through visible light and electrical current/potential is possible with PECs having $p$-type semiconductor cathodes (either modified/sensitized or not) which are activated by light and transfer successively electrons from the conduction band of the illuminated semiconductor to the $\mathrm{LUMO}$ of $\mathrm{CO}_{2}[163,164]$. This approach is based on a process of photoelectrolysis $[165,166]$ where an electrical current accomplishes the same function of the sacrificial agent in the analogous process of photochemical reduction $[167,168]$. Beside radiation exploitation, the main advantages of the photoelectrochemical approach for $\mathrm{CO}_{2}$ transformation are the fine control over electrical current and applied potential, the avoidance of the replenishment of sacrificial agent employed in the non-electrochemical processes, low temperature of 
operation, the general easiness of separation and purification procedures and, more importantly, the general attainment of relatively large TON values with respect to the photochemical processes [169].

When compared to photoelectrochemically induced HER [170-172], the analogous process of $\mathrm{CO}_{2}$ reduction $[173,174]$ presents the main general inconvenience of not producing a single product with consequent ill-definition of the value(s) of electrical potential to apply in photoelectrolytic regime as well as the specific wavelengths at which carbon dioxide electroreduction can be photoactivated. Because of that, the faradic efficiencies for carbon dioxide photoelectroreduction will result generally much lower (Table 6, vide infra) than those achieved in the photoelectrochemical generation of $\mathrm{H}_{2}$ (nearly $100 \%$ in most cases, vide supra) for which the binding of two $\mathrm{H}$ (ad)atoms is the sole chemical process associated to the electrochemical reduction of $\mathrm{H}^{+}$representing the starting species [170-172]. In case of the photoelectrochemical reduction of $\mathrm{CO}_{2}$ the following elementary steps have been recognized as necessary provided the existence of a dye-sensitizer and a catalyst which in an electron-rich state coordinates $\mathrm{CO}_{2}$ and transfers one or more electrons to carbon dioxide following dye-sensitizer excitation [21,175-179]:

(a) Formation of the excited state of the dye-sensitizer upon light absorption (step of charge separation);

(b) Excitation (or electron) transfer from the dye-sensitizer to the catalytic species that coordinates carbon dioxide (ET step);

(c) Electron transfer from the coordinating species (electron relay) to carbon dioxide (ET step);

(d) Uptake of electron(s) from an electron donor, i.e., the $p$-type semiconducting (photo)electrode, by the dye-sensitizer and/or the electron relay species that resulted oxidized for occurrence of steps (b) and (c);

Occurrence of the latter step (d) requires the passage of an electrical current to start again the whole reduction cycle. In Table 6 some photocathodic materials and photoelectrocatalysts for the light activated electrochemical reduction of $\mathrm{CO}_{2}$ in potentiostatic conditions are reported with the specification of the reduction products and the faradic efficiency [175,176,178-182].

Table 6. Semiconducting $p$-type and metallic electrodes for the photo- and electro-chemical reduction of $\mathrm{CO}_{2}$. The electron relays, the conditions of photoelectrolysis and faradic efficiencies are also reported.

\begin{tabular}{|c|c|c|c|c|c|}
\hline $\begin{array}{c}p \text {-Type or Metal } \\
\text { Electrode }\end{array}$ & Electron Relay & $\begin{array}{c}\text { Applied } \\
\text { Potential/V }\end{array}$ & Product & $\begin{array}{c}\text { Faradic } \\
\text { Efficiency } / \%\end{array}$ & Reference \\
\hline $\mathrm{FeS}_{2}$ & imidazole & -0.68 vs. SCE & $\mathrm{CO}$ & 2.4 & [178] \\
\hline $\mathrm{FeS}_{2}$ & imidazole & -0.68 vs. SCE & $\mathrm{HCO}_{2} \mathrm{H}$ & 4.9 & [178] \\
\hline $\mathrm{FeS}_{2}$ & pyridine & -0.60 vs. SCE & $\mathrm{HCO}_{2} \mathrm{H}$ & 2.7 & [178] \\
\hline $\mathrm{Cu}_{2} \mathrm{O} / \mathrm{CuO} n$-rods & - & -0.20 vs. SHE & $\mathrm{CH}_{3} \mathrm{OH}$ & 95 & [179] \\
\hline CIS & - & -0.60 vs. SHE & $\mathrm{CO}$ & 20 & [180] \\
\hline $\mathrm{Au}$ & - & -1.35 vs. SHE & $\mathrm{CO}$ & 42 & [181] \\
\hline $\mathrm{Au} / \operatorname{Re}$ & - & -1.35 vs. SHE & $\mathrm{CO}$ & 87 & [181] \\
\hline $\mathrm{Ag}$ & methyl viologen & -0.60 vs. SCE & $\mathrm{CO}$ & - & [175] \\
\hline $\mathrm{Cu}^{1}$ & - & 0.75 vs. SHE & $\mathrm{CH}_{4}$ & 67 & [182] \\
\hline $\mathrm{Sn} / \mathrm{SnO}_{x}{ }^{1}$ & - & 0.70 vs. SHE & $\mathrm{HCO}_{2} \mathrm{H}$ & 27.5 & [182] \\
\hline $\mathrm{ZnS}$ & - & -0.60 vs. SCE & $\mathrm{HCO}_{2} \mathrm{H}$ & 20 & [176] \\
\hline
\end{tabular}

From the results schematically presented in Table 6 the most encouraging results appear those obtained with $\mathrm{WO}_{3}-\mathrm{Cu}$ [181] and $\mathrm{Cu}_{2} \mathrm{O} / \mathrm{CuO}$ [179] cathodes for a series of reasons: (i) the relatively high faradic efficiency $(>65 \%)$ due to the specificity of the reduction process in the adopted conditions of photoelectrolysis; (ii) the absence of an electron relay which denotes the existence of intrinsic electrocatalytic properties in the chosen semiconducting electrodes [this would lead to skip step (b), vide supra, with resulting improvement of the kinetics]; (iii) the nature of the final products (methanol 
and methane) which contain a high number of hydrogen atoms $(3 / 4)$ per molecule and constitute highly energetic fuels.

In Figure 20 some possible schemes of photoelectrocatalytic conversion of carbon dioxide are presented when the $p$-type electrode is the actual light-absorbing species. Among the various photoelectrode configurations here shown in Figure 20, the designs that offer more synthetic versatility are those which include the participation of a molecular catalyst (like the $\operatorname{Re}(\mathrm{I})$ carbonyl complex of Figure 20, right column) the structure of which can be varied in a plethora of ways. The richness of the synthetic chemistry of molecular photocatalysts for $\mathrm{CO}_{2}$ reduction can be somehow estimated by the number of examples reported in Figures 21-24 [169,183]. These complexes represent well known photocatalysts acting as photoreducing agent in homogeneous conditions of photoreduction $([169,183]$ and references therein). A possible step forward in the field of photocathode definition for carbon dioxide photoelectrochemical reduction is the immobilization of these light absorbing materials onto opportune electrode surfaces, which would act as dye-sensitizers towards $\mathrm{CO}_{2}$ photoelectrochemical reduction utilizing the same working principle of a $p$-DSC $[36,184]$.

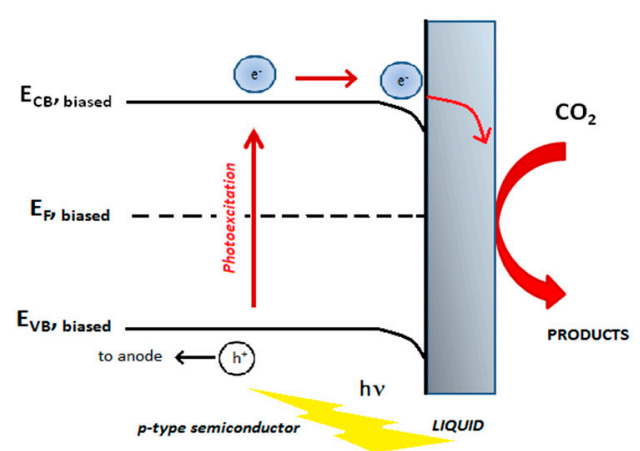

(a)

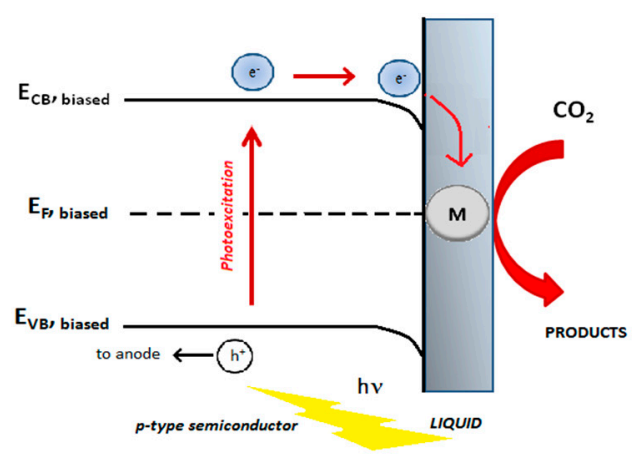

(c)

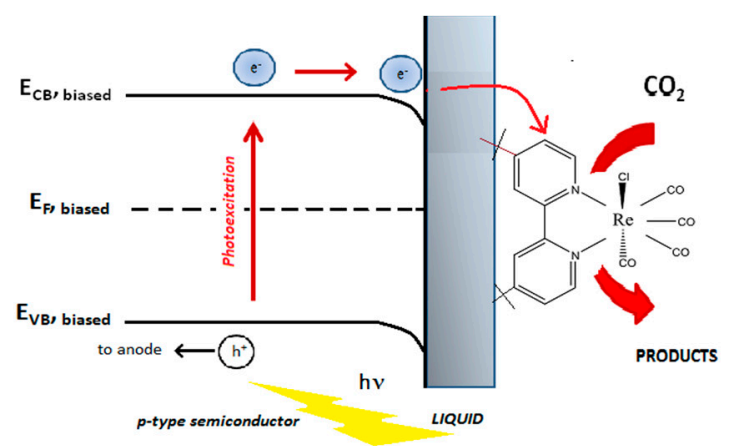

(b)

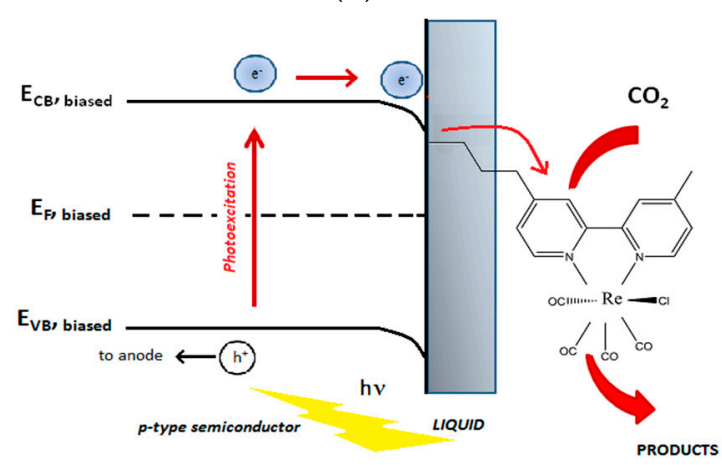

(d)

Figure 20. Schematic representation of four possible mechanisms of light-assisted $\mathrm{CO}_{2}$ reduction on a $p$-type semiconducting photocathode: (a) heterogeneous photoelectrocatalysis on a semiconductor electrode; (b) homogeneous catalysis through a molecular catalyst in the electrolyte; (c) heterogeneous catalysis on a metal-decorated semiconductor electrode; (d) heterogeneous catalysis via a molecular catalyst anchored on the semiconductor electrode. The $p$-type semiconductor represents the light-absorbing species. Adapted from reference [21]. 

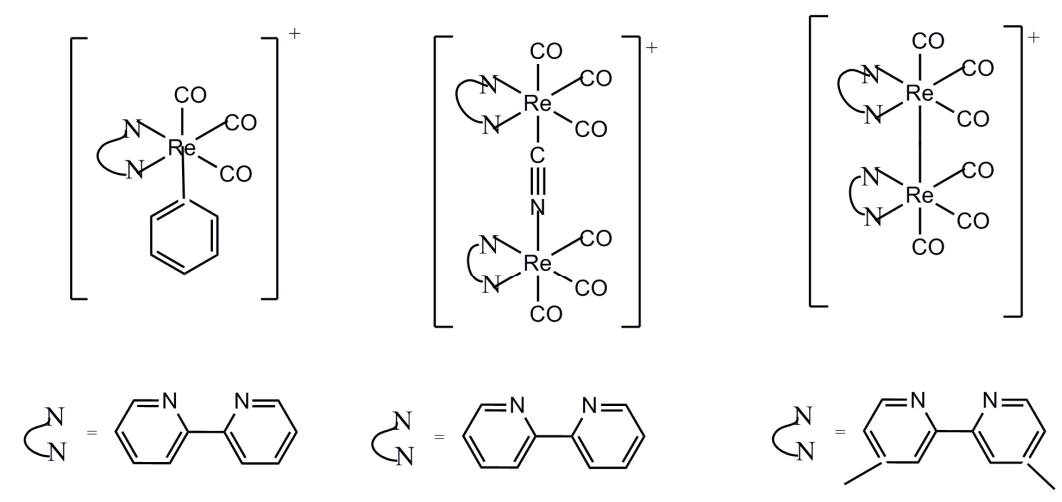

$\mathrm{R}=\mathrm{H}, \mathrm{CH} 3, \mathrm{C}(\mathrm{CH} 3) 3, \mathrm{CN}, \mathrm{CO}(\mathrm{CH} 3)$

Figure 21. Some examples of $\operatorname{Re}(\mathrm{I})$ mononuclear and binuclear complexes with pyridyl ligands, which behave as molecular photocatalysts in the photoactivated reduction of $\mathrm{CO}_{2}([169,183]$ and references therein).
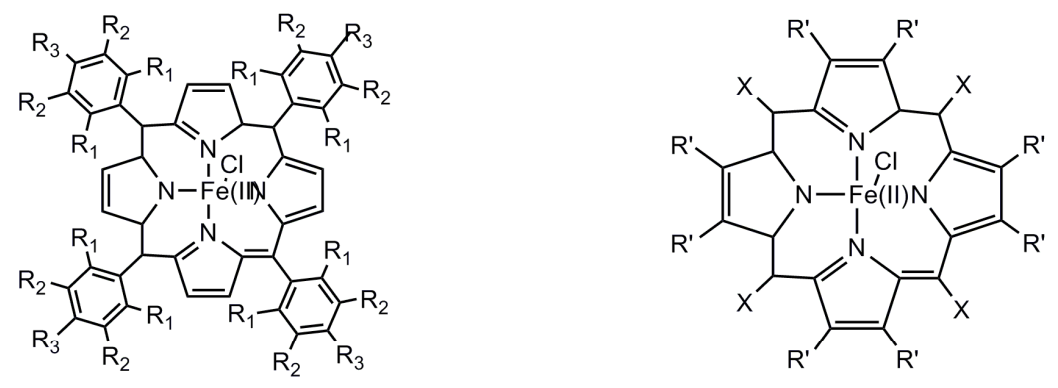

$$
\begin{aligned}
& \mathrm{R}_{1}, \mathrm{R}_{2}, \mathrm{R}_{3}=\mathrm{H} \\
& \mathrm{R}_{1}, \mathrm{R}_{3}=\mathrm{CH}_{3} \quad \mathrm{R}_{2}=\mathrm{H} \\
& \mathrm{R}_{1}=\mathrm{Cl} \quad \mathrm{R}_{2}, \mathrm{R}_{3}=\mathrm{H} \\
& \mathrm{R}_{1}, \mathrm{R}_{2}, \mathrm{R}_{3}=\mathrm{F} \\
& \mathrm{R}_{1}, \mathrm{R}_{2}=\mathrm{H} \quad \mathrm{R}_{3}=\mathrm{SO}_{3} \mathrm{H}
\end{aligned}
$$

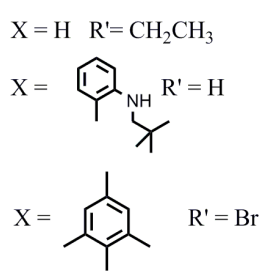

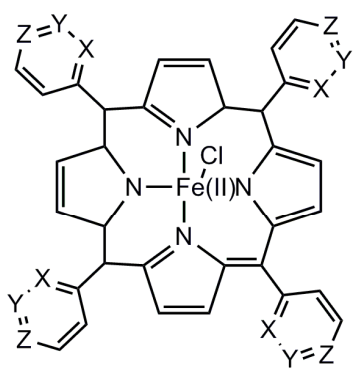

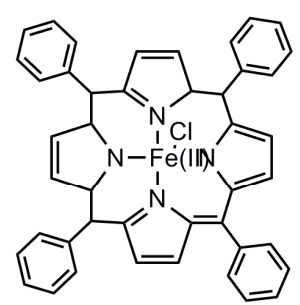

$$
\begin{array}{ll}
X=Y=C H, & Z=N H \\
X=Z=C H, & Y=N H \\
Y=Z=C H, & X=N H
\end{array}
$$

Figure 22. Some examples of Fe(III) porphyrins with different peripheral substituents which act as molecular photocatalysts in the process of photoactivated $\mathrm{CO}_{2}$ reduction $([169,183]$ and references therein). 

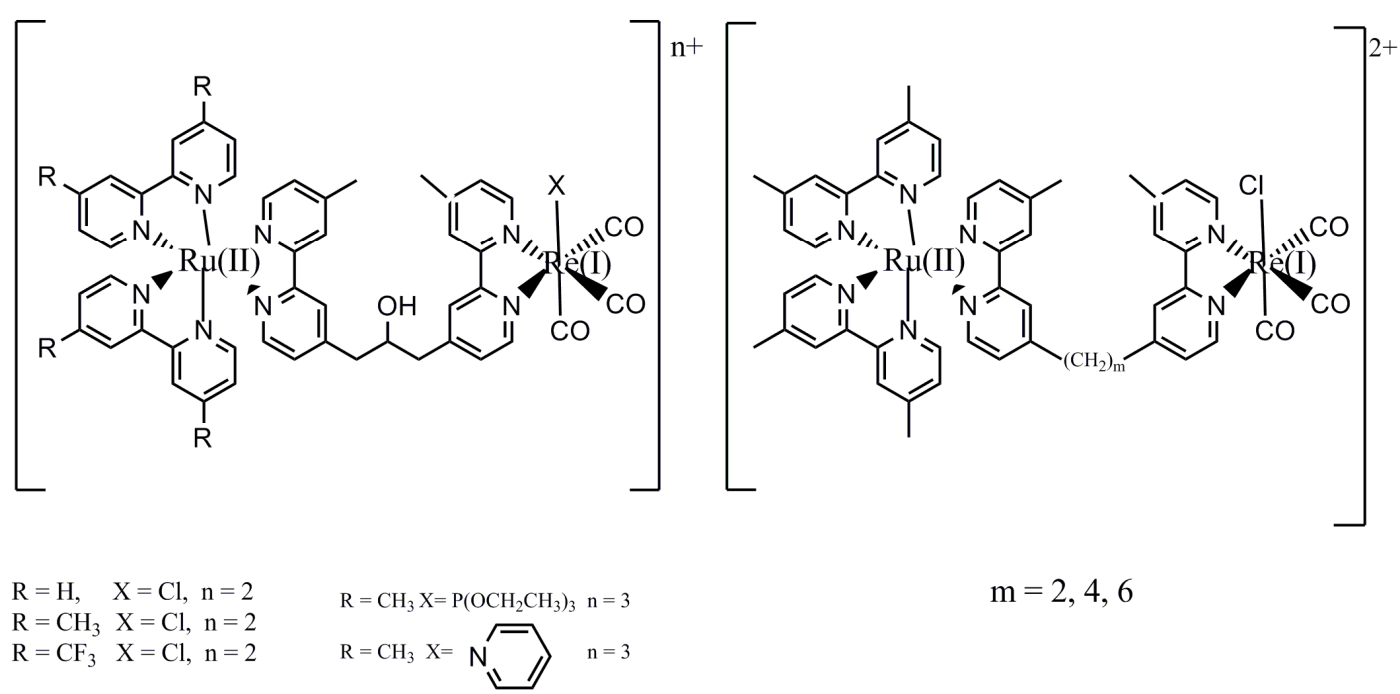

$\mathrm{m}=2,4,6$

Figure 23. Some examples of binuclear complexes of $\operatorname{Re}(\mathrm{I})$ and $\mathrm{Ru}(\mathrm{II})$ acting as molecular photocatalysts in the process of photoactivated $\mathrm{CO}_{2}$ reduction $([169,183]$ and references therein).

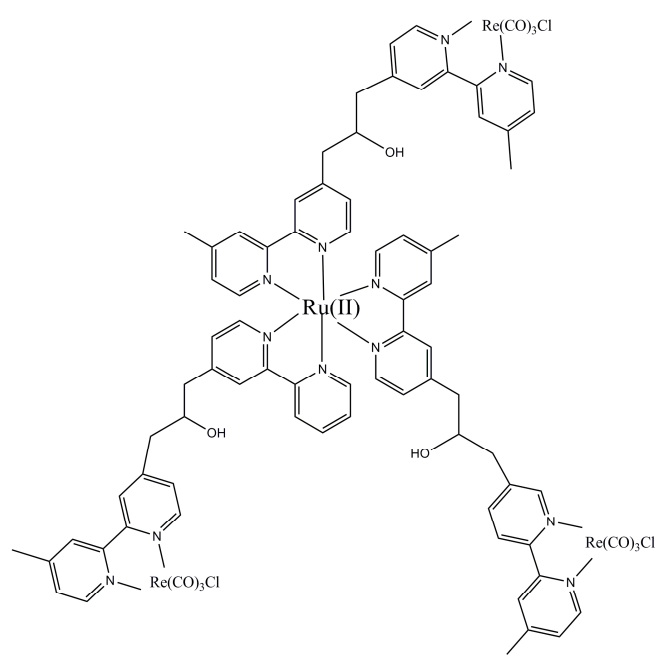

(a)

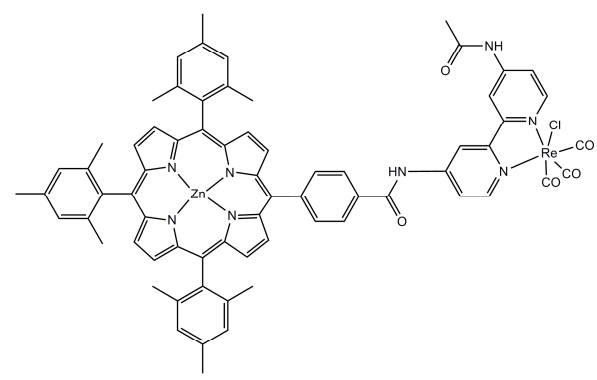

(b)

Figure 24. An example of (a) trinuclear complex of Re(I)-Ru(II); and (b) binuclear $\mathrm{Zn}(\mathrm{II})-\operatorname{Re}(\mathrm{I})$ complex with porphyrin ligand utilized as molecular photocatalysts for the photoactivation of $\mathrm{CO}_{2}$ reduction $([169,183]$ and references therein).

\section{Summary}

The uses of $p$-type semiconductors as photocathodes of PECs have been reviewed as far as the applications of $p$-DSCs, $t$-DSCs, solar generation of $\mathrm{H}_{2}$ fuel and photoreduction of carbon dioxide were concerned. In particular, we have considered the most recent developments in those technologies and configurations of PECs which require the utilization of semiconductors having nanostructured features and mesoporous morphology. With such a morphology the resulting $p$-type cathodes can afford extended surface areas and are prone to be efficaciously modified by opportune dye-sensitizers, catalysts and functional coatings which photo-/electro-activate the desired electrochemical process of reduction. Among these technologies the PECs with photoactive cathodes can be distinguished in primary cells, like in the case of light fueled $p$-DSC which convert light intensity in electrical power, and in photoelectrolysis cells which require the simultaneous consumption of luminous energy and electrical power for the successive formation of the desired reduction product(s). Some 
authors have recently outlined how the same cathodic material in a $p$-type PEC can be successfully employed for both types of uses, i.e., primary or secondary cell, provided that the triple combination semiconducting cathode/sensitizer-catalyst/redox shuttle realizes photoactived reduction processes that are exergonic and endergonic in the primary and electrolysis photocell, respectively. A crucial issue related to the employment of nanostructured semiconducting cathodes is the determination of the actual energy level scheme for the frontier states that are directly involved in the transport of mobile charge carriers as well as the optical absorption. Different to a semiconductor in a compact version, the actual energy level diagram is originated by poorly delocalized states which create a generally ill-defined band structure as a consequence of the confined nature of the constituting units of nanoparticulate. This intrinsic difficulty requires particularly strong efforts in the process of definition, preparation and characterization of the new mesoporous cathodes and sensitizers/catalysts for a given destination of the cathodic PEC. Beside the identification and characterization of the isolated nanostructured electrode, the successive fundamental step is constituted by the characterization of the interfaces obtained by the combination of the mesoporous semiconductor with the functional materials acting as photo-/electro-catalysts, the semiconducting scaffold representing the actual photoinjected charge collector. In this framework surface spectroscopic techniques become necessary auxiliaries of photoelectrochemical characterization techniques for designing and predicting properties of the various interfaces in a PEC. The most recently presented combinations of photoactive materials for the four types of cathodic PECs here reviewed are characterized by the large variety of the choices. Among nanostructured semiconducting cathodes nickel oxide (either stoichiometric or defective) represents the main actor and it has been proposed in almost any kind of nanoshape in the majority of the contributions on $p$-type PECs. On the other hand, the review shows also that the presence of $p$-type materials like $\mathrm{CuAlO}_{2}, \mathrm{CuGaO}_{2}, \mathrm{CuCrO}_{2}, \mathrm{FeS}_{2}, \mathrm{Cu}_{2} \mathrm{O}, \mathrm{SnO}_{x}, \mathrm{ZnS}$ and $\mathrm{K}_{x} \mathrm{ZnO}$ in the same research ambit is no longer marginal and is finding encouragement in the steady improvement of the photoconversion performances. The large number of new colorants and electrocatalysts (of molecular nature in almost any case) that are continuously reported with success in the literature renders practically impossible any serious effort in compiling an all-embracing list of these functional materials when the four important applications of $p$-DSC, $t$-DSC, $\mathrm{H}_{2}$ solar generation and $\mathrm{CO}_{2}$ photoreduction are considered at the same time. Electronic conjugation, presence of structural spacers or substituents with specific electronic effects, functions and positions, state of surface immobilization, eventual presence of localised charges or excited electronic state properties are just few of the most important factors controlling the realization of the processes of charge photogeneration and injection. In the stage of molecular design the influence of all these architectural elements on the performance of the resulting functional system in general is very hard to predict no matter of the kind of $p$-type photoconversion device. Additionally, researchers have to consider also the feasibility of the synthesis and purification methods for these purposely designed photo-/electro-catalytic systems. Depending on the nature of $p$-type photoconversion device we could recognize that the motivations inspiring the conduct of research are generally diverse. For example, in terms of short-term goals, the main purpose of the work on $p$-DSCs is the achievement of overall efficiencies that are comparable with the ones commonly obtained by the best performing $n$-DSCs in order to develop adequate $t$-DSCs with resulting efficiencies that approach the theoretical limits. In the other case of the photoproduction of $\mathrm{H}_{2}$ fuel there is the attempt of translating the working principles of $p$ - and $t$-DSCs towards new $p$-type electrolytic PECs through the adoption of different types of catalysts and decoration of the nanostructured electrode with respect to the primary cells. Beside materials related issues, the questions associated to flow-cell engineering are also important especially for the delivery and storage of a gaseous (and explosive) photoproduct like $\mathrm{H}_{2}$. When the process of $\mathrm{CO}_{2}$ photoelectrochemical reduction in $p$-type PECs is analyzed other types of difficulties are encountered by the researchers. First of all, there is no unambiguous identification of the actual mechanism of $\mathrm{CO}_{2}$ photoelectrochemical reduction via the mediation of a photocatalyst and an electron relay agent since any specific combination of nanostructured/cathode/sensitizer/catalyst/electrolyte will lead to a different succession of elementary steps. Beside the limits in the knowledge of the mechanism of photoelectrocatalysis there are also the difficulties of the non-existence of a single-valued photopotential of reduction (and, 
therefore, the non-existence of a univocal photoreduction product), as well as the non-identification of the actual electron-donating species and the form under which the $\mathrm{CO}_{2}$ substrate is attacked by it. The present situation indicates that the community of photoelectrochemists involved in the development of PECs for $\mathrm{CO}_{2}$ photoreduction is not ready yet to assign a definitive architecture to the cell of photoelectrolysis as well as to choose a distinctive combination of photoelectroactive materials. In the mare magnum of the still unexplored combinations there is little room then for worrying about the way of increasing the photoconversion efficiencies of the $p$-type PECs which somehow phototransform carbon dioxide.

Acknowledgments: Authors wish to thank the University of Rome LA SAPIENZA for financial support through the project Ateneo Sapienza (protocol no: 2011/VG1-C26A11PKS2). Moreover, authors gratefully acknowledge the financial support from Ministero dell'Istruzione dell'Università e della Ricerca-MIUR (project title: DSSCX; protocol No.: PRIN ( Progetto di Rilevante Interesse Nazionale) 2010-2011, 20104XET32) for the realization of experiments which have been presented in some works cited by the present review Danilo Dini wishes to acknowledge past financial support from Science Foundation Ireland (SFI Project No. 07/SRC/B1160) for the realization of experiments which have been presented in some works cited by the present review. Danilo Dini thanks also Johannes Gerard Vos from the School of Chemical Sciences at Dublin City University (DCU), Ireland, for profitable discussion.

Author Contributions: Both authors contributed in the same way to the compilation of the reference list, figures preparation and text organization.

Conflicts of Interest: The authors declare no conflict of interest.

\section{Abbreviations}

The following abbreviations are used in this manuscript:

$\begin{array}{ll}\text { PEC } & \text { photo-electrochemical cell } \\ \text { ET } & \text { electron transfer } \\ \text { DSC } & \text { dye-sensitized solar cell } \\ \text { VB } & \text { valence band } \\ \text { CB } & \text { conduction band } \\ \text { IPCE } & \text { incident photon-to-current conversion efficiency } \\ \text { APCE } & \text { absorbed photon-to-current conversion efficiency } \\ \text { LUMO } & \text { lowest unoccupied molecular orbital } \\ \text { HOMO } & \text { highest occupied molecular orbital } \\ \text { FF } & \text { fill factor } \\ \text { PMI-6T-TPA } & \text { perylene-monoimide-hexathiophene-triphenylamine } \\ \text { NPs } & \text { nanoparticles } \\ \text { HER } & \text { hydrogen evolution reaction } \\ \text { PMI-4T-TPA } & \text { perylene-monoimide-tetra(hexyl-thiophene)-triphenylamine } \\ \text { QD } & \text { quantum dots } \\ \text { TON } & \text { turnover number } \\ \text { SHE } & \text { standard hydrogen electrode } \\ \text { QE } & \text { quantum efficiency } \\ \text { IP } & \text { ionization potential energy } \\ \text { STH } & \text { solar energy to hydrogen conversion } \\ \text { GDY } & \text { graphdiyne } \\ \text { NWs } & \text { nanowires } \\ \text { RGO } & \text { reduced graphene oxide } \\ \text { QRE } & \text { quasi-reference electrode } \\ \text { CNT } & \text { carbon nanotubes } \\ \text { MSE } & \text { mercury/mercurous sulfate electrode } \\ \text { NF } & \text { nanostructured film } \\ \mu-p y & \text { micropyramids } \\ \text { ELD } & \text { electroless deposit } \\ \text { NM } & \text { nanomesh } \\ \text { SCE } & \text { standard calomel electrode } \\ \mu W s & \text { microwires } \\ \text { CIS } & \end{array}$




\section{References}

1. Hagfeldt, A.; Grätzel, M. Light-induced redox reactions in nanocrystalline systems. Chem. Rev. 1995, 95, 49-68. [CrossRef]

2. O'Regan, B.; Grätzel, M. A low-cost, high-efficiency solar cell based on dye-sensitized colloidal TiO 2 films. Nature 1991, 353, 737-740. [CrossRef]

3. Ito, S.; Murakami, T.N.; Comte, P.; Liska, P.; Grätzel, C.; Nazeeruddin, M.K.; Grätzel, M. Fabrication of thin film dye sensitized solar cells with solar to electric power conversion efficiency over $10 \%$. Thin Solid Films 2008, 516, 4613-4619. [CrossRef]

4. Yella, A.; Lee, H.W.; Tsao, H.N.; Yi, C.; Chandiran, A.K.; Nazeeruddin, M.K.; Diau, E.W.G.; Yeh, C.Y.; Zakeeruddin, S.M.; Grätzel, M. Porphyrin-sensitized solar cells with cobalt (II/III)-based redox electrolyte 719 exceed 12 percent efficiency. Science 2011, 334, 629-634. [CrossRef] [PubMed]

5. Mathew, S.; Yella, A.; Gao, P.; Humphry-Baker, R.; Curchod, B.F.E.; Ashari-Astani, N.; Tavernelli, I.; Rothlisberger, U.; Nazeeruddin, M.K.; Grätzel, M. Dye-sensitized solar cells with 13\% efficiency achieved through the molecular engineering of porphyrin sensitizers. Nat. Chem. 2014, 6, 242-247. [CrossRef] [PubMed]

6. Gerischer, H.; Michel-Beyerle, M.E.; Rebentrost, F.; Tributsch, H. Sensitization of charge injection into semiconductors with large band gap. Electrochim. Acta 1968, 13, 1509-1515. [CrossRef]

7. Dini, D. Nanostructured metal oxide thin films as photoactive cathodes of $p$-type dye-sensitised solar cells. Phys. Chem. Commun. 2016, 3, 14-51.

8. Bisquert, J.; Zaban, A.; Salvador, P. Analysis of the mechanisms of electron recombination in nanoporous $\mathrm{TiO}_{2}$ dye-sensitized solar cells. Nonequilibrium Steady-State Statistics and Interfacial Electron Transfer via Surface States. J. Phys. Chem. B 2002, 106, 8774-8782. [CrossRef]

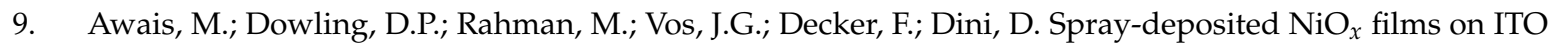
substrates as photoactive electrodes for $p$-type dye-sensitized solar cells. J. Appl. Electrochem. 2013, 43, 191-197. [CrossRef]

10. Gibson, E.A.; Awais, M.; Dini, D.; Dowling, D.P.; Pryce, M.T.; Vos, J.G.; Boschloo, G.; Hagfeldt, A. Dye sensitized solar cells with nickel oxide photocathodes prepared via scalable microwave sintering. Phys. Chem. Chem. Phys. 2013, 15, 2411-2420. [CrossRef] [PubMed]

11. Awais, M.; Gibson, E.; Vos, J.G.; Dowling, D.P.; Hagfeldt, A.; Dini, D. Fabrication of efficient NiO photocathodes prepared via RDS with novel routes of substrate processing for $p$-type dye-sensitized solar cells. ChemElectroChem 2014, 2, 384-391. [CrossRef]

12. He, J.; Lindström, H.; Hagfeldt, A.; Lindquist, S.E. Dye-sensitized nanostructured tandem cell-first demonstrated cell with a dye-sensitized photocathode. Sol. Energy Mater. Sol. Cells 2000, 62, 265-273. [CrossRef]

13. Sheehan, S.; Naponiello, G.; Odobel, F.; Dowling, D.P.; Di Carlo, A.; Dini, D. Comparison of the photoelectrochemical properties of RDS $\mathrm{NiO}$ thin films for $p$-type DSCs with different organic and organometallic dye-sensitizers and evidence of a direct correlation between cell efficiency and charge recombination. J. Solid State Electrochem. 2015, 19, 975-986. [CrossRef]

14. Venditti, I.; Barbero, N.; Russo, M.V.; Di Carlo, A.; Decker, F.; Fratoddi, I.; Barolo, C.; Dini, D. Electrodeposited $\mathrm{ZnO}$ with squaraine sensitizers as photoactive anode of DSCs. Mater. Res. Exp. 2014, 1. [CrossRef]

15. Borgström, M.; Blart, E.; Boschloo, G.; Mukhtar, E.; Hagfeldt, A.; Hammarström, L.; Odobel, F. Sensitized hole injection of phosphorous porphyrin into NiO: Toward new photovoltaic devices. J. Phys. Chem. B 2005, 109, 22928-22934. [CrossRef] [PubMed]

16. Nayak, P.K.; Garcia-Belmont, G.; Kahn, A.; Bisquert, J.; Cahen, D. Photovoltaic efficiency limits and material disorder. Energy Environ. Sci. 2012, 5, 6022-6039. [CrossRef]

17. Grätzel, M. Photoelectrochemical cells. Nature 2001, 414, 338-344. [CrossRef] [PubMed]

18. Bisquert, J.; Fabregat-Santiago, F. Impedance spectroscopy: A general introduction and application to dye-sensitized solar cells. In Dye-Sensitized Solar Cells; Kalyanasundaram, K., Ed.; EPFL Press: Lausanne, Switzerland, 2010; pp. 457-554.

19. Dini, D.; Halpin, Y.; Vos, J.G.; Gibson, E.A. The influence of the preparation method of $\mathrm{NiO}_{x}$ photocathodes on the efficiency of $p$-type dye-sensitised solar cells. Coord. Chem. Rev. 2015, 304-305, 179-201. [CrossRef] 
20. Holladay, J.D.; Hu, J.; King, D.L.; Wang, Y. An overview of hydrogen production technologies. Catal. Today 2009, 139, 244-260. [CrossRef]

21. Kumar, B.; Llorente, M.; Froehlich, J.; Dang, T.; Sathrum, A.; Kubiak, C.P. Photochemical and Photoelectrochemical Reduction of $\mathrm{CO}_{2}$. Annu. Rev. Phys. Chem. 2012, 63, 24-29. [CrossRef] [PubMed]

22. Tryk, D.A.; Fujishima, A.; Honda, K. Recent topics in photoelectrochemistry: Achievements and future prospects. Electrochim. Acta 2000, 45, 2363-2376. [CrossRef]

23. Lewis, N.S. New directions and challenges in electrochemistry: frontiers of research in photoelectrochemical solar energy conversion. J. Appl. Electrochem. 2001, 508, 1-10.

24. Tian, H. Molecular catalyst immobilized photocathodes for water/proton and carbon dioxide reduction. Chem. Sustain. Chem. 2015, 8, 3746-3759. [CrossRef] [PubMed]

25. Kakiage, K.; Aoyama, Y.; Yano, T.; Otsuka, T.; Kyomen, T.; Unno, M.; Hanaya, M. An achievement of over 12 percent efficiency in an organic dye-sensitized solar cell. Chem. Commun. 2014, 50, 6379-6381. [CrossRef] [PubMed]

26. Kakiage, K.; Aoyama, Y.; Yano, T.; Oya, K.; Kyomen, T.; Hanaya, M. Fabrication of a high-performance dye-sensitized solar cell with $12.8 \%$ conversion efficiency using organic silyl-anchor dyes. Chem. Commun. 2015, 51, 6315-6317. [CrossRef] [PubMed]

27. Kakiage, K.; Aoyama, Y.; Yano, T.; Oya, K.; Fujisawa, J.I.; Hanaya, M. Highly-efficient dye-sensitized solar cells with collaborative sensitization by silyl-anchor and carboxy-anchor dyes. Chem. Commun. 2015, 51, 15894-15897. [CrossRef] [PubMed]

28. Nakasa, A.; Usami, H.; Sumikura, S.; Hasegawa, S.; Koyama, T.; Suzuki, E. A high voltage dye-sensitized solar cell using a nanoporous $\mathrm{NiO}$ photocathode. Chem. Lett. 2005, 34, 500-501. [CrossRef]

29. Nattestad, A.; Mozer, A.J.; Fischer, M.K.R.; Cheng, Y.B.; Mishra, A.; Bäuerle, P.; Bach, U. Highly efficient photocathodes for dye-sensitized tandem solar cells. Nat. Mater. 2010, 9, 31-35. [CrossRef] [PubMed]

30. Wood, C.J.; Summers, G.H.; Gibson, E.A. Increased photocurrent in a tandem dye-sensitized solar cell by modifications in push-pull dye-design. Chem. Commun. 2015, 51, 3915-3918. [CrossRef] [PubMed]

31. Gibson, E.A.; Smeigh, A.L.; Le Pleux, L.; Fortage, J.; Boschloo, G.; Blart, E.; Hammarström, L. A p-type $\mathrm{NiO}-$ based dye-sensitized solar cell with an open-circuit voltage of $0.35 \mathrm{~V}$. Angew. Chem. Int. Ed. 2009, 48, 4402-4405. [CrossRef] [PubMed]

32. Shockley, W.; Queisser, H.J. Detailed balance limit of efficiency of $p-n$ junction solar cells. J. Appl. Phys. 1961, 32, 510-519. [CrossRef]

33. Henry, C.H. Limiting efficiencies of ideal single and multiple energy gap terrestrial solar cells. J. Appl. Phys. 1980, 51, 4494-4500. [CrossRef]

34. Urbani, M.; Grätzel, M.; Nazeeruddin, M.K.; Torres, T. Meso-Substituted Porphyrins for Dye-Sensitized Solar Cells. Chem. Rev. 2014, 114, 12330-12396. [CrossRef] [PubMed]

35. Weidelener, M.; Mishra, A.; Nattestad, A.; Powar, S.; Mozer, A.J.; Mena-Osteritz, E.; Cheng, Y.B.; Bach, U.; Bäuerle, P. Synthesis and characterization of perylene-bithiophene-triphenylamine triads: Studies on the effect of alkyl-substitution in $p$-type $\mathrm{NiO}$ based photocathodes. J. Mater. Chem. 2012, 22, 7366-7379. [CrossRef]

36. Wood, C.J.; Summers, G.H.; Clark, C.A.; Kaeffer, N.; Brauetigam, M.; Carbone, L.R.; D'Amario, L.; Fan, K.; Farré, Y.; Narbey, S.; et al. A comprehensive comparison of dye-sensitized $\mathrm{NiO}$ photocathodes for solar energy conversion. Phys. Chem. Chem. Phys. 2016. [CrossRef] [PubMed]

37. Li, L.; Gibson, E.A.; Qin, P.; Boschloo, G.; Gorlov, M.; Hagfeldt, A.; Sun, L.C. Double-Layered NiO Photocathodes for $p$-Type DSSCs with Record IPCE. Adv. Mater. 2010, 22, 1759-1762. [CrossRef] [PubMed]

38. Powar, S.; Wu, Q.; Weidelener, M.; Nattestad, A.; Hu, Z.; Mishra, A.; Bäuerle, P.; Spiccia, L.; Cheng, Y.B.; Bach, U. Improved photocurrents for $p$-type dye-sensitized solar cells using nano-structured nickel(II) oxide microballs. Energy Environ. Sci. 2012, 5, 8896-8900. [CrossRef]

39. Zhang, X.L.; Huang, F.; Nattestad, A.; Wang, K.; Fu, D.; Mishra, A.; Bäuerle, P.; Bach, U.; Cheng, Y.B. Enhanced open-circuit voltage of $p$-type DSC with highly crystalline $\mathrm{NiO}$ nanoparticles. Chem. Commun. 2011, 47, 4808-4810. [CrossRef] [PubMed]

40. Sumikura, S.; Mori, S.; Shimizu, S.; Usami, H.; Suzuki, E. Syntheses of NiO nanoporous films using nonionic triblock co-polymer templates and their application to photo-cathodes of $p$-type dye-sensitized solar cells. J. Photochem. Photobiol. A 2008, 199, 1-7. [CrossRef] 
41. Awais, M.; Rahman, M.; MacElroy, J.M.D.; Dini, D.; Vos, J.G.; Dowling, D.P. Application of a novel microwave plasma treatment for the sintering of nickel oxide coatings for use in dye-sensitized solar cells. Surf. Coat. Technol. 2011, 205, S245-S249. [CrossRef]

42. Perera, I.R.; Daeneke, T.; Makuta, S.; Yu, Z.; Tachibana, Y.; Mishra, A.; Bäuerle, P.; Ohlin, C.A.; Bach, U.; Spiccia, L. Application of the tris(acetylacetonato)iron(III)/(II) redox couple in $p$-type dye-sensitized solar cells. Angew. Chem. Int. Ed. 2015, 54, 3758-3762. [CrossRef] [PubMed]

43. Powar, S.; Daeneke, T.; Ma, M.T.; Fu, D.; Duffy, N.W.; Götz, G.; Weidelener, M.; Mishra, A.; Bäuerle, P.; Spiccia, L.; Bach, U. Highly efficient $p$-type dye-sensitized solar cells basedon tris(1,2-diaminoethane)cobalt(II)/(III) electrolytes. Angew. Chem. Int. Ed. 2013, 52, 602-605. [CrossRef] [PubMed]

44. Powar, S.; Bhargava, R.; Daeneke, T.; Götz, G.; Bäuerle, P.; Geiger, T.; Kuster, S.; Nüesch, F.A.; Spiccia, L.; Bach, U. Thiolate/disulfide based electrolytes for $p$-type and tandem dye-sensitized solar cells. Electrochim. Acta 2015, 182, 458-463. [CrossRef]

45. Xu, X.; Zhang, B.; Cui, J.; Xiong, D.; Shen, Y.; Chen, W.; Sun, L.; Cheng, Y.; Wang, M. Efficient $p$-type dye-sensitized solar cells based on disulfide/thiolate electrolytes. Nanoscale 2013, 5, 7963-7969. [CrossRef] [PubMed]

46. Daeneke, T.; Yu, Z.; Lee, G.P.; Fu, D.; Duffy, N.W.; Makuta, S.; Tachibana, Y.; Spiccia, L.; Mishra, A.; Bäuerle, P.; et al. Dominating energy losses in $\mathrm{NiO}$ p-type dye-sensitized solar cells. Adv. Energy Mater. 2015, 5. [CrossRef]

47. Smeigh, A.L.; Le Pleux, L.; Fortage, J.; Pellegrin, Y.; Blart, E.; Odobel, F.; Hammarström, L. Ultrafast recombination for $\mathrm{NiO}$ sensitized with a series of perylene imide sensitizers exhibiting Marcus normal behaviour. Chem. Commun. 2012, 48, 678-680. [CrossRef] [PubMed]

48. D'Amario, L.; Antila, L.J.; Pettersson Rimgard, B.; Boschloo, G.; Hammarström, L. Kinetic evidence of two pathways for charge recombination in NiO-based dye-sensitized solar cells. J. Phys. Chem. Lett. 2015, 6, 779-783. [CrossRef] [PubMed]

49. Boschloo, G.; Hagfeldt, A. Spectroelectrochemistry of nanostructured NiO. J. Phys. Chem. B 2001, 105, 3039-3044. [CrossRef]

50. Novelli, V.; Awais, M.; Dowling, D.P.; Dini, D. Electrochemical characterization of rapid discharge sintering (RDS) $\mathrm{NiO}$ cathodes for dye-sensitized solar cells of $p$-Type. Am. J. Anal. Chem. 2015, 6, 176-187. [CrossRef]

51. Awais, M.; Dowling, D.P.; Decker, F.; Dini, D. Electrochemical characterization of nanoporous nickel oxide thin films spray-deposited onto indium-doped tin oxide for solar conversion scopes. Adv. Cond. Matter Phys. 2015. [CrossRef]

52. Ursu, D.; Miclau, M.; Banica, R.; Vaszilcsin, N. Impact of Fe doping on performances of $\mathrm{CuGaO}_{2} p$-type dye-sensitized solar cells. Mater. Lett. 2015, 143, 91-93. [CrossRef]

53. Yu, M.; Natu, G.; Ji, Z.; Wu, Y. p-type dye-sensitized solar cells based on delafossite $\mathrm{CuGaO}_{2}$ nanoplates with saturation photovoltages exceeding $460 \mathrm{mV}$. J. Phys. Chem. Lett. 2012, 3, 1074-1078. [CrossRef] [PubMed]

54. Renaud, A.; Chavillon, B.; Le Pleux, L.; Pellegrin, Y.; Blart, E.; Boujtita, M.; Pauporté, T.; Cario, L.; Jobic, S.; Odobel, F. $\mathrm{CuGaO}_{2}$ : A promising alternative for $\mathrm{NiO}$ in $p$-type dye solar cells. J. Mater. Chem. 2012, 22, 14353-14356. [CrossRef]

55. Bandara, J.; Yasomanee, J.P. $p$-type oxide semiconductors as hole collectors in dye-sensitized solid-state solar cells. Semicond. Sci. Technol. 2007, 22, 20-24. [CrossRef]

56. Nattestad, A.; Zhang, X.; Bach, U.; Cheng, Y.B. Dye-sensitized $\mathrm{CuAlO}_{2}$ photocathodes for tandem solar cell applications. J. Photon. Energy 2011, 1. [CrossRef]

57. Siripala, W.; Premasiri Kumara, K. A photoelectrochemical investigation of the $n$ - and $p$-type semiconducting behaviour of copper(I) oxide films. Semicond. Sci. Technol. 1989, 4, 465-468. [CrossRef]

58. Bai, J.; Xu, X.; Xu, L.; Cui, J.; Huang, D.; Chen, W.; Cheng, Y.; Shen, Y.; Wang, M. Potassium-doped zinc oxide as photocathode material in dye-sensitized solar cells. ChemSusChem 2013, 6, 622-629. [CrossRef] [PubMed]

59. Zhang, X.L.; Zhang, Z.; Huang, F.; Bäuerle, P.; Bach, U.; Cheng, Y.B. Charge transport in photocathodes based on the sensitization of $\mathrm{NiO}$ nanorods. J. Mater. Chem. 2012, 22, 7005-7009. [CrossRef]

60. Xiong, D.; Xu, Z.; Zeng, X.; Zhang, W.; Chen, W.; Xu, X.; Wang, M.; Cheng, Y.B. Hydrothermal synthesis of ultrasmall $\mathrm{CuCrO}_{2}$ nanocrystal alternatives to $\mathrm{NiO}$ nanoparticles in efficient $p$-type dye-sensitized solar cells. J. Mater. Chem. 2012, 22, 24760-24768. [CrossRef] 
61. Le Pleux, L.; Smeigh, A.L.; Gibson, E.; Pellegrin, Y.; Blart, E.; Boschloo, G.; Hagfeldt, A.; Hammarström, L.; Odobel, F. Synthesis, photophysical and photovoltaic investigations of acceptor-functionalized perylene monomide dyes for nickel oxide p-type dye-sensitized solar cells. Energy Environ. Sci. 2011, 4, 2075-2084. [CrossRef]

62. Luo, J.; Steier, L.; Son, M.K.; Schreier, M.; Mayer, M.T.; Grätzel, M. Cu글 nanowire photocathodes for efficient and durable solar water splitting. Nano Lett. 2016, 16, 1848-1857. [CrossRef] [PubMed]

63. Hellstern, T.R.; Benck, J.D.; Kibsgaard, J.; Hahn, C.; Jaramillo, T.F. Engineering cobalt phosphide (CoP) thin film catalysts for enhanced hydrogen evolution activity on silicon photocathodes. Adv. Energy Mater. 2016, 6, 1501758-1501765. [CrossRef]

64. You, B.; Jiang, N.; Sheng, M.; Bhushan, M.W.; Sun, Y. Hierarchically porous urchin-like $\mathrm{Ni}_{2} \mathrm{P}$ superstructures supported on nickel foam as efficient bifunctional electrocatalysts for overall water splitting. ACS Catal. 2016, 6, 714-721. [CrossRef]

65. Gao, L.; Cui, Y.; Vervuurt, R.H.J.; Van Dam, D.; Van Veldhoven, R.P.J.; Hofmann, J.P.; Bol, A.A.; Haverkort, J.E.M.; Notten, P.H.L.; Bakkers, E.P.A.M.; et al. High-efficiency InP-based photocathode for hydrogen production by interface energetics design and photon management. Adv. Funct. Mater. 2016, 26, 679-686. [CrossRef]

66. Morales-Guio, C.G.; Liardet, L.; Mayer, M.T.; Tilley, S.D.; Grätzel, M.; Hu, X. Photoelectrochemical hydrogen production in alkaline solutions using $\mathrm{Cu}_{2} \mathrm{O}$ coated with earth-abundant hydrogen evolution catalysts. Angew. Chem. Int. Ed. 2015, 54, 664-667. [CrossRef]

67. McCrory, C.C.L.; Jung, S.; Ferrer, I.M.; Chatman, S.M.; Peters, J.C.; Jaramillo, T.F. Benchmarking hydrogen evolving reaction and oxygen evolving reaction electrocatalysts for solar water splitting devices. J. Am. Chem. Soc. 2015, 137, 4347-4357. [CrossRef] [PubMed]

68. Kwak, I.H.; Im, H.S.; Jang, D.M.; Kim, Y.W.; Park, K.; Lim, Y.R.; Cha, E.H.; Park, J. CoSe 2 and NiSe 2 nanocrystals as superior bifunctional catalysts for electrochemical and photoelectrochemical water splitting. ACS Appl. Mater. Interfaces 2016, 8, 5327-5334. [CrossRef] [PubMed]

69. Becker, J.P.; Urbain, F.; Smirnov, V.; Rau, U.; Ziegler, J.; Kaiser, B.; Jaegermann, W.; Finger, F. Modeling and practical realization of thin film silicon-based integrated solar water splitting devices. Phys. Status Solidi A 2016, 1-9. [CrossRef]

70. Lewis, N.S. Research opportunities to advance solar energy utilization. Science 2016, 351. [CrossRef] [PubMed]

71. Walter, M.G.; Warren, E.J.; McKone, J.R.; Boettcher, S.W.; Mi, Q.; Santori, E.A.; Lewis, N.S. Solar water splitting cells. Chem. Rev. 2010, 110, 6446-6471. [CrossRef] [PubMed]

72. Ruberu, P.A.; Dong, Y.; Das, A.; Eisenberg, R.T. Photoelectrochemical generation of hydrogen from water using a CdSe quantum dot-sensitized photocathode. ACS Catal. 2015, 5, 2255-2259. [CrossRef]

73. Dong, Y.; Wu, R.; Jiang, P.; Wang, G.; Chen, Y.; Wu, X.; Zhang, C. Efficient photoelectrochemical hydrogen generation from water using a robust photocathode formed by CdTe QDs and nickel ion. ACS Sustain. Chem. Eng. 2015, 3, 2429-2434. [CrossRef]

74. Ji, Z.; He, M.; Huang, Z.; Ozkan, U.; Wu, Y. Photostable $p$-type dye-sensitized photoelectrochemical cells for water reduction. J. Am. Chem. Soc. 2013, 135, 11696-11699. [CrossRef] [PubMed]

75. Click, K.A.; Beauchamp, D.R.; Huang, Z.; Chen, W.; Wu, Y. Membrane-inspired acidically stable dye-sensitized photocathode for solar fuel production. J. Am. Chem. Soc. 2016, 138, 1174-1179. [CrossRef] [PubMed]

76. Tong, L.; Iwase, A.; Nattestad, A.; Bach, U.; Weidelener, M.; Götz, G.; Mishra, A.; Bäuerle, P.; Amal, R.; Wallace, G.G.; et al. Sustained solar hydrogen generation using a dye-sensitised $\mathrm{NiO}$ photocathode $/ \mathrm{BiVO}_{4}$ tandem photo-electrochemical device. Energy Environ. Sci. 2012, 5, 9472-9475. [CrossRef]

77. Castillo, C.E.; Gennari, M.; Stoll, T.; Fortage, J.; Deronzier, A.; Collomb, M.N.; Sandroni, M.; Légalité, F.; Blart, E.; Pellegrin, Y.; et al. Visible light-driven electron transfer from a dye-sensitized $p$-type NiO photocathode to a molecular catalyst in solution: Toward $\mathrm{NiO}$ based photoelectrochemical devices for solar hydrogen production. J. Phys. Chem. C 2015, 119, 5806-5818. [CrossRef]

78. Meng, P.; Wang, M.; Yang, Y.; Zhang, S.; Sun, L. CdSe quantum dots/molecular cobalt catalyst co-grafted open porous $\mathrm{NiO}$ film as a photocathode for visible light driven $\mathrm{H}_{2}$ evolution from neutral water. J. Mater. Chem. A 2015, 3, 18852-18860. [CrossRef] 
79. Dong, Y.; Chen, Y.; Jiang, P.; Wang, G.; Wu, X.; Wu, R.; Zhang, C. Efficient Stable $\mathrm{MoS}_{2} / \mathrm{CdSe} / \mathrm{NiO}$ photocathode for photoelectrochemical hydrogen generation from water. Chem. Asian J. 2015, 10, 1660-1667. [CrossRef] [PubMed]

80. Siripala, W.; Ivanovskaya, A.; Jaramillo, T.F.; Baeck, S.H.; McFarland, E.W.A. $\mathrm{Cu}_{2} \mathrm{O} / \mathrm{TiO}_{2}$ heterojunction thin film cathode for photoelectrocatalysis. Sol. Energy Mater. Sol. Cells 2003, 77, 229-237. [CrossRef]

81. Morales-Guio, C.G.; Tilley, S.D.; Vrubel, H.; Grätzel, M.; Hu, X. Hydrogen evolution from a copper(I) oxide photocathode coated with an amorphous molybdenum sulphide catalyst. Nat. Commun. 2014, 5, 3059-3065. [CrossRef] [PubMed]

82. Amano, F.; Ebina, T.; Ohtani, B. Enhancement of photocathodic stability of $p$-type copper(I) oxide electrodes by surface etching treatment. Thin Solid Films 2014, 550, 340-346. [CrossRef]

83. Hsu, Y.K.; Yu, C.H.; Lin, H.H.; Chen, Y.C.; Lin, Y.G. Template synthesis of copper oxide nanowires for photoelectrochemical hydrogen generation. J. Electroanal. Chem. 2013, 704, 19-23. [CrossRef]

84. Chiang, C.Y.; Shin, Y.; Li, S.E. Doped CuO film electrodes for photoelectrochemical cells. J. Electrochem. Soc. 2011, 159, B227-B231. [CrossRef]

85. Fan, W.; Yu, X.; Lu, H.C.; Bai, H.; Zhang, C.; Shi, W. Fabrication of $\mathrm{TiO}_{2} / \mathrm{RGO} / \mathrm{Cu}_{2} \mathrm{O}$ heterostructure for photoelectrochemical hydrogen production. Appl. Catal. B 2016, 181, 7-15. [CrossRef]

86. Paracchino, A.; Laporte, V.; Sivula, K.; Grätzel, M.; Thimsen, E. Highly active oxide photocathode for photoelectrochemical water reduction. Nat. Mater. 2011, 10, 456-461. [CrossRef] [PubMed]

87. Malerba, C.; Biccari, F.; Azanza Ricardo, C.L.; D’Incau, M.; Scardi, P.; Mittiga, A. Absorption coefficient of bulk and thin film $\mathrm{Cu}_{2} \mathrm{O}$. Sol. Energy Mater. Sol. Cells 2011, 95, 2848-2854. [CrossRef]

88. Nian, J.N.; Hu, C.C.; Teng, H. Electrodeposited $p$-type $\mathrm{Cu}_{2} \mathrm{O}$ for $\mathrm{H}_{2}$ evolution from photoelectrolysis of water under visible light illumination. Int. J. Hydrog. Energy 2008, 33, 2897-2903. [CrossRef]

89. Hu, C.; Chu, K.; Zhao, Y.; Teoh, W.Y. Efficient Photoelectrochemical Water Splitting over Anodized $p$-Type NiO Porous Films. ACS Appl. Mater. Interfaces 2014, 6, 18558-18568. [CrossRef] [PubMed]

90. Chiang, C.Y.; Aroh, K.; Franson, N.; Satsangi, V.R.; Dass, S.; Ehrman, S. Copper oxide nanoparticle made by flame spray pyrolysis for photoelectrochemical water splitting. Part II. Photoelectrochemical study. Int. J. Hydrog. Energy 2011, 36, 15519-15526. [CrossRef]

91. Aroutiounian, V.M.; Arakelyan, V.M.; Shahnazaryan, G.E. Metal oxide photoelectrodes for hydrogen generation using solar radiation-driven water splitting. Sol. Energy 2005, 78, 581-592. [CrossRef]

92. Vincent, T.; Gross, M.; Dotan, H.; Rothschild, A. Thermally oxidized iron oxide nanoarchitectures for hydrogen production by solar-induced water splitting. Int. J. Hydrog. Energy 2012, 37, 8102-8109. [CrossRef]

93. Lopes, T.; Andrade, L.; Aguilar Ribeiro, H.; Mendes, A. Transient phenomenological modeling of photoelectrochemical cells for water splitting-Application to undoped hematite electrodes. Int. J. Hydrog. Energy 2011, 36, 175-188.

94. Cao, J.; Kako, T.; Li, P.; Ouyang, S.; Ye, J. Fabrication of $p$-type $\mathrm{CaFe}_{2} \mathrm{O}_{4}$ nanofilms for photoelectrochemical hydrogen generation. Electrochem. Commun. 2011, 13, 275-278. [CrossRef]

95. Yu, Q.; Meng, X.; Wang, T.; Li, P.; Liu, L.; Chang, K.; Liu, G.; Ye, J. A highly durable $p$-LaFeO $\mathrm{O}_{3} / n-\mathrm{Fe}_{2} \mathrm{O}_{3}$ photocell for effective water splitting under visible light. Chem. Commun. 2015, 51, 3630-3633. [CrossRef] [PubMed]

96. Sun, Y.; Liu, C.; Grauer, D.C.; Yano, J.; Long, J.R.; Yang, P.; Chang, C.J. Electrodeposited Cobalt-Sulfide Catalyst for Electrochemical and Photoelectrochemical Hydrogen Generation from water. J. Am. Chem. Soc. 2013, 135, 17699-17702. [CrossRef] [PubMed]

97. Chen, C.J.; Chen, P.T.; Basu, M.; Yang, K.C.; Lu, Y.R.; Dong, C.L.; Ma, C.G.; Shen, C.C.; Hu, S.F.; Liu, R.S. An integrated cobalt disulfide $\left(\mathrm{CoS}_{2}\right)$ co-catalyst passivation layer on silicon microwires for photoelectrochemical hydrogen evolution. J. Mater. Chem. A 2015, 3, 23466-23476. [CrossRef]

98. Andoshe, D.M.; Jeon, J.M.; Kim, S.Y.; Jang, H.W. Two-Dimensional Transition Metal Dichalcogenide Nanomaterials for Solar Water Splitting. Electron. Mater. Lett. 2015, 11, 323-335. [CrossRef]

99. Ding, Q.; Zhai, J.; Cabán-Acevedo, M.; Shearer, M.J.; Li, L.; Chang, H.C.; Tsai, M.L.; Ma, D.; Zhang, X.; Hamers, R.J.; He, J.R.; Jin, S. Designing efficient solar-driven hydrogen evolution photocathodes using semitransparent $\mathrm{MoQ}_{x} \mathrm{Cl}_{y}(\mathrm{Q}=\mathrm{S}$, Se) catalysts on Si micropyramids. Adv. Mater. 2015, 27, 6511-6518. [CrossRef] [PubMed]

100. Zhang, X.; Meng, F.; Mao, S.; Ding, Q.; Shearer, M.J.; Faber, M.S.; Chen, J.; Hamers, R.J.; Jin, S. Amorphous $\mathrm{MoS}_{\mathrm{x}} \mathrm{Cl}_{\mathrm{y}}$ electrocatalyst supported by vertical graphene for efficient electrochemical and photoelectrochemical hydrogen generation. Energy Environ. Sci. 2015, 8, 862-868. [CrossRef] 
101. Chang, K.; Hai, X.; Ye, J. Transition Metal Disulfides as Noble-Metal-Alternative Co-Catalysts for Solar Hydrogen Production. Adv. Energy Mater. 2016, 6, 1502555-1502575.

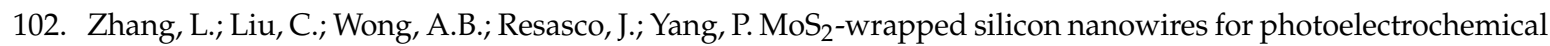
water reduction. Nano Res. 2015, 8, 281-287. [CrossRef]

103. Ding, Q.; Meng, F.; English, C.R.; Cabán-Acevedo, M.; Shearer, M.J.; Liang, D.; Daniel, A.S.; Hamers, R.J.; Jin, S. Efficient photoelectrochemical hydrogen generation using heterostructures of Si and chemically exfoliated metallic MoS 2 . J. Am. Chem. Soc. 2014, 136, 8504-8508. [CrossRef] [PubMed]

104. Chen, Y.; Tran, P.D.; Boix, P.; Ren, Y.; Chiam, S.Y.; Li, Z.; Fu, K.; Wong, L.H.; Barber, J. Silicon decorated with amorphous cobalt molybdenum sulfide catalyst as an efficient photocathode for solar hydrogen generation. ACS Nano 2015, 9, 3829-3836. [CrossRef] [PubMed]

105. Wang, M.; Jiang, J.; Shi, J.; Guo, L. CdS/CdSe core-shell nanorod arrays: energy level alignment and enhanced photoelectrochemical performance. ACS Appl. Mater. Interfaces 2013, 5, 4021-4025. [PubMed]

106. Rodenas, P.; Song, T.; Sudhagar, P.; Marzari, G.; Han, H.; Badia-Bou, L.; Gimenez, S.; Fabregat-Santiago, F.; Mora-Sero, I.; Bisquert, J.; et al. Quantum dot based heterostructures for unassisted photoelectrochemical hydrogen generation. Adv. Energy Mater. 2013, 3, 176-182. [CrossRef]

107. Zhao, J.; Minegishi, T.; Zhang, L.; Zhong, M.; Nakabayashi, M.; Ma, G.; Hisatomi, T.; Katayama, M.; Ikeda, S.; Shibata, N.; et al. Enhancement of solar hydrogen evolution from water by surface modification with CdS and $\mathrm{TiO}_{2}$ on porous $\mathrm{CuInS} 2$ photocathodes prepared by an electrodeposition-sulfurization method. Angew. Chem. Int. Ed. 2014, 53, 11808-11812. [CrossRef] [PubMed]

108. Barkschat, A.; Tributsch, H.; Dohrmann, J.K. Imaging of catalytic activity of platinum on $p$-InP for photocathodical hydrogen evolution. Sol. Energy Mater. Sol. Cells 2003, 80, 391-403. [CrossRef]

109. Gao, L.; Cui, Y.; Wang, J.; Cavalli, A.; Standing, A.; Vu, T.T.T.; Verheijen, M.A.; Haverkort, J.E.M.; Bakkers, E.P.A.M.; Notten, P.H.L. Photoelectrochemical hydrogen production on InP nanowire arrays with molybdenum sulfide electrocatalysts. Nano Lett. 2014, 14, 3715-3719. [CrossRef] [PubMed]

110. Cedeno, D.; Krawicz, A.; Doak, P.; Yu, M.; Neaton, J.B.; Moore, G.F. Using molecular design to control the performance of hydrogen-producing polymer-brush-modified photocathodes. J. Phys. Chem. Lett. 2014, 5, 3222-3226. [CrossRef] [PubMed]

111. Basu, M.; Zhang, Z.W.; Chen, C.J.; Chen, P.T.; Yang, K.C.; Ma, C.G.; Lin, C.C.; Hu, S.F.; Liu, R.S. Heterostructure of $\mathrm{Si} \mathrm{CoSe}$ : A promising photocathode based on a non-noble metal catalyst for photoelectrochemical hydrogen evolution. Angew. Chem. 2015, 127, 6309-6314. [CrossRef]

112. Tu, W.H.; Hsu, Y.K.; Yen, C.H.; Wu, C.; Hwang, J.S.; Chen, L.C.; Chen, K.H. Au nanoparticle modified GaN photoelectrode for photoelectrochemical hydrogen generation. Electrochem. Commun. 2011, 13, 530-533. [CrossRef]

113. Han, Q.; Wang, B.; Zhao, Y.; Hu, C.; Qu, L. A graphitic- $\mathrm{C}_{3} \mathrm{~N}_{4}$ "Seaweed" architecture for enhanced hydrogen evolution. Angew. Chem. Int. Ed. 2015, 54, 11433-11437. [CrossRef] [PubMed]

114. Masa, J.; Weide, P.; Peeters, D.; Sinev, I.; Xia, W.; Sun, Z.; Somsen, C.; Muhler, M.; Schuhmann, W. Amorphous cobalt Boride $\left(\mathrm{CO}_{2} \mathrm{~B}\right)$ as a highly efficient nonprecious catalyst for electrochemical water splitting: oxygen and hydrogen evolution. Adv. Energy Mater. 2016, 6, 1502313-1502322. [CrossRef]

115. Döscher, H.; Supplie, O.; May, M.M.; Sippel, P.; Heine, C.; Muňoz, A.G.; Eichberger, R.; Lewerenz, H.J.; Hannappel, T. Epitaxial III-V films and surfaces for photoelectrocatalysis. Chem. Phys. Chem. 2012, 13, 2899-2909.

116. Licht, S. Multiple band gap semiconductor/electrolyte solar energy conversion. J. Phys. Chem. B 2001, 105, 6281-6294. [CrossRef]

117. Van Dorp, D.H.; Hijnen, N.; Di Vece, M.; Kelly, J.J. SiC: A Photocathode for Water Splitting and Hydrogen Storage. Angew. Chem. Int. Ed. 2009, 48, 6085-6088. [CrossRef] [PubMed]

118. Ma, Q.B.; Ziegler, J.; Kaiser, B.; Fertig, D.; Calvet, W.; Murugasen, E.; Jaegermann, W. Solar water splitting with $p$-SiC film on $p$-Si: Photoelectrochemical behavior and XPS characterization. Int. J. Hydrog. Energy 2014, 39, 1623-1629. [CrossRef]

119. Huang, Q.; Ye, Z.; Xiao, X. Recent progress in photocathodes for hydrogen evolution. J. Mater. Chem. A 2015, 3, 15824-15837. [CrossRef]

120. Zhuang, H.L.; Hennig, R.C. Computational search for single-layer transition metal dicholcogenide photocatalysts. J. Phys: Chem. C 2013, 117, 20440-20445.

121. Peter, L.M.; Wijayantha, K.G.U. Photoelectrochemical water splitting at semiconductor electrodes: Fundamental problems and new perspectives. Chem. Phys. Chem. 2014, 15, 1983-1995. [CrossRef] [PubMed] 
122. Moriya, M.; Minegishi, T.; Kumagai, H.; Katayama, M.; Kubota, J.; Domen, K. Stable hydrogen evolution drom CdS-modified CuGaSe 2 photoelectrode under visible-light irradiation. J. Am. Chem. Soc. 2013, 135, 3733-3735. [CrossRef] [PubMed]

123. Li, J.; Gao, X.; Liu, B.; Feng, Q.; Li, X.B.; Huang, M.Y.; Liu, Z.; Zhang, J.; Tung, C.H.; Wu, L.Z. Graphdiyne: A metal-free material as hole transfer layer to fabricate quantum dot-sensitized photocathodes for hydrogen production. J. Am. Chem. Soc. 2016, 138, 3954-3957. [CrossRef] [PubMed]

124. Xie, G.; Zhang, K.; Guo, B.; Liu, Q.; Fang, L.; Gong, J.R. Graphene-based materials for hydrogen generation from light-driven water splitting. Adv. Mater. 2013, 25, 3820-3839. [CrossRef] [PubMed]

125. Babenko, S.D.; Galakai, A.A.; Lavrushko, A.G.; Moskvin, Y.L.; Sharaaev, S.N. Kinetic analysis of photoelectrochemical hydrogen evolution over $p$-type silicon in acidic aqueous solutions of electrolytes. Russ. Chem. Bull. 2000, 49, 1707-1711. [CrossRef]

126. Boettcher, S.W.; Warren, E.L.; Putnam, M.C.; Santori, E.A.; Turner-Evans, D.; Kelzenberg, M.D.; Walter, M.G.; McKone, J.R.; Brunschwig, B.S.; Atwater, H.A.; Lewis, N.S. Photoelectrochemical hydrogen evolution using Si microwire arrays. J. Am. Chem. Soc. 2011, 133, 1216-1227. [CrossRef] [PubMed]

127. Oh, I. Photoelectrochemical hydrogen production on textured silicon photocathode. J. Korea Electrochem. Soc. 2011, 14, 191-195. [CrossRef]

128. Oh, I.; Kye, J.; Hwang, S. Fabrication of metal-semiconductor interface in porous silicon and its photoelectrochemical hydrogen production. Bull. Korean Chem. Soc. 2011, 32, 4392-4396. [CrossRef]

129. Oh, I.; Kye, J.; Hwang, S. Enhanced photoelectrochemical hydrogen production from silicon nanowire array photocathode. Nano Lett. 2012, 12, 298-302. [CrossRef] [PubMed]

130. Kye, J.; Shin, M.; Lim, B.; Jang, J.W.; Oh, I.; Hwang, S. Platinum monolayer electrocatalyst on gold nanostructures on silicon for photoelectrochemical hydrogen evolution. ACS Nano 2013, 7, 6017-6023. [CrossRef] [PubMed]

131. Dai, P.; Xie, J.; Mayer, M.T.; Yang, X.; Zhan, J.; Wang, D. Solar hydrogen generation by silicon nanowires modified with platinum nanoparticle catalysts by atomic layer deposition. Angew. Chem. Int. Ed. 2013, 52, 11119-11123. [CrossRef] [PubMed]

132. Lai, Y.H.; Park, H.S.; Zhang, J.Z.; Matthews, P.D.; Wright, D.S.; Reisner, E. A Si photocathode protected and activated with a Ti and Ni composite film for solar hydrogen production. Chem. Eur. J. 2015, 21, 3919-3923. [CrossRef] [PubMed]

133. Ziegler, J.; Kaiser, B.; Jaegermann, W.; Urbain, F.; Becker, J.P.; Smirnov, V.; Finger, F. Photoelectrochemical and photovoltaic characteristics of amorphous-silicon-based tandem cells as photocathodes for water splitting. Chem. Phys. Chem. 2014, 15, 4026-4031. [CrossRef] [PubMed]

134. Lee, D.H.; Kobaku, S.P.R.; Hong, Y.T.; Kwon, J.Y. An efficient photoelectrochemical hydrogen evolution system using silicon nanomaterials with ultra-high aspect ratios. Energy Technol. 2014, 2, 889-896. [CrossRef]

135. Huang, Z.; McKone, J.R.; Xiang, C.; Grimm, R.L.; Warren, E.L.; Spurgeon, J.M.; Lewerenz, H.J.; Brunschwig, B.S.; Lewis, N.S. Comparison between the measured and modeled hydrogen-evolution activity of Ni- or Pt-coated silicon photocathodes. Int. J. Hydrog. Energy 2014, 39, 16220-16226. [CrossRef]

136. Kaiser, B.; Calvet, W.; Murugasen, E.; Ziegler, J.; Jaegermann, W.; Pust, S.E.; Finger, F.; Hoch, S.; Blug, M.; Busse, J. Light induced hydrogen generation with silicon-based thin film tandem solar cells used as photocathode. Int. J. Hydrog. Energy 2015, 40, 899-904. [CrossRef]

137. Jung, J.Y.; Park, M.Y.; Li, X.; Kim, J.H.; Wehrspohn, R.B.; Lee, J.H. High performance $\mathrm{H}_{2}$ evolution realized in $20 \mathrm{~mm}$ thin silicon nanostructured photocathodes. J. Mater. Chem. A 2015, 3, 9456-9460. [CrossRef]

138. Lichterman, M.F.; Sun, K.; Hu, S.; Zhou, X.; McDowell, M.T.; Shaner, M.R.; Richter, M.H.; Crumlin, E.J.; Carim, A.I.; Saadi, F.H.; et al. Protection of inorganic semiconductors for sustained, efficient photoelectrochemical water oxidation. Catal. Today 2016, 262, 11-23. [CrossRef]

139. Licht, S. Efficient solar generation of hydrogen fuel-A fundamental analysis. Electrochem. Commun. 2002, 4, 790-795. [CrossRef]

140. McKone, J.R.; Lewis, N.S.; Gray, H.B. Will solar-driven water-splitting devices see the light of day? Chem. Mater. 2014, 26, 407-414. [CrossRef]

141. Rodriguez, C.A.; Modestino, M.A.; Psaltis, D.; Moser, C. Design and cost considerations for practical solar hydrogen generators. Energy Environ. Sci. 2014, 7, 3828-3835. [CrossRef]

142. Bak, T.; Nowotny, J.; Rekas, M.; Sorrell, C.C. Photo-electrochemical hydrogen generation from water using solar energy. Materials-related aspects. Int. J. Hydrog. Energy 2002, 27, 991-1022. [CrossRef] 
143. Licht, S. Solar water splitting to generate hydrogen fuel: A photothermal electrochemical analysis. Int. J. Hydrog. Energy 2005, 30, 459-470. [CrossRef]

144. Kelly, N.A.; Gibson, T.H. Solar energy concentrating reactors for hydrogen production by photoelectrochemical water splitting. Int. J. Hydrog. Energy 2008, 33, 6420-6431. [CrossRef]

145. Licht, S.; Wang, B.; Mukerji, S.; Soga, T.; Umeno, M.; Tributsch, H. Over $18 \%$ solar energy conversion to generation of hydrogen fuel; theory and experiment for efficient solar water splitting. Int. J. Hydrog. Energy 2001, 26, 653-659. [CrossRef]

146. Murphy, A.B.; Barnes, P.R.F.; Randeniya, L.K.; Plumb, I.C.; Grey, I.E.; Horne, M.D.; Glasscock, J.A. Efficiency of solar water splitting using semiconductor electrodes. Int. J. Hydrog. Energy 2006, 31, 1999-2017. [CrossRef]

147. Li, X.; Yu, J.; Low, J.; Fang, Y.; Xiao, J.; Chen, X. Engineering heterogeneous semiconductors for solar water splitting. J. Mater. Chem. A 2015, 3, 2485-2534. [CrossRef]

148. Nowotny, J.; Sorrell, C.C.; Bak, T.; Sheppard, L.R. Solar-hydrogen: Unresolved problems in solid-state science. Sol. Energy 2005, 78, 593-602. [CrossRef]

149. Aresta, M.; Dibenedetto, A.; Angelini, A. Catalysis for the valorization of exhaust carbon: From $\mathrm{CO}_{2}$ to chemicals, materials, and fuels. Technological use of $\mathrm{CO}_{2}$. Chem. Rev. 2014, 114, 1709-1742. [CrossRef] [PubMed]

150. European Space Agency (ESA)-online document on Climate Change Initiative Programme. Available online: http:/ / esamultimedia.esa.int/docs/EarthObservation/ESA_CCI_140605.pdf (accessed on 11 May 2016).

151. Sutin, N.; Creutz, C.; Fujita, E. Photo-induced generation of dihydrogen and reduction of carbon dioxide using transition metal complexes. Commun. Inorg. Chem. 1997, 19, 67-92. [CrossRef]

152. Tanaka, K.; Ooyama, D. Multi-electron reduction of $\mathrm{CO}_{2}$ via $\mathrm{RuCO}_{2}, \mathrm{C}(\mathrm{O}) \mathrm{OH}, \mathrm{CO}, \mathrm{CHO}$ and $\mathrm{CH}_{2} \mathrm{OH}$ species. Coord. Chem. Rev. 2002, 226, 211-218.

153. Leitner, W. The coordination chemistry of carbon dioxide and its relevance for catalysis: A critical survey. Coord. Chem. Rev. 1996, 153, 257-284. [CrossRef]

154. Benson, E.E.; Kubiak, C.P.; Sathrum, A.J.; Smieja, J.M. Electrocatalytic and homogeneous approaches to conversion of $\mathrm{CO}_{2}$ to liquid fuels. Chem. Soc. Rev. 2009, 38, 89-99. [CrossRef] [PubMed]

155. Chaplin, R.P.S.; Wragg, A.A. Effects of process conditions and electrode material on reaction pathways for carbon dioxide electroreduction with particular reference to formate formation. J. Appl. Electrochem. 2003, 33, 1107-1123. [CrossRef]

156. Gattrell, M.; Gupta, N.; Co, A. A review of the aqueous electrochemical reduction of $\mathrm{CO}_{2}$ to hydrocarbons at copper. J. Electroanal. Chem. 2006, 594, 1-19. [CrossRef]

157. Hatsukade, T.; Kuhl, K.P.; Cave, E.R.; Abram, D.N.; Jaramillo, T.F. Insights into the electrocatalytic reduction of $\mathrm{CO}_{2}$ on metallic silver surfaces. Phys. Chem. Chem. Phys. 2014, 16, 13814-13819. [CrossRef] [PubMed]

158. Begum, A.; Pickup, P.G. Electrocatalysis of $\mathrm{CO}_{2}$ reduction by ruthenium benzothiazole and thiazole complexes. Electrochem. Commun. 2007, 9, 2525-2528. [CrossRef]

159. Angamuthu, R.; Byers, P.; Lutz, M.; Spek, A.L.; Bouwman, E. Electrocatalytic $\mathrm{CO}_{2}$ Conversion to Oxalate by a Copper Complex. Science 2010, 327, 313-315. [CrossRef] [PubMed]

160. Aresta, M.; Dibenedetto, A. Utilisation of $\mathrm{CO}_{2}$ as chemical feedstock: Opportunities and challenges. Dalton Trans. 2007, 2975-2992. [CrossRef] [PubMed]

161. Indrakanti, V.P.; Kubicki, J.D.; Schobert, H.H. Photoinduced activation of $\mathrm{CO}_{2}$ on Ti-based heterogeneous catalysts: Current state, chemical physics-based insights and outlook. Energy Environ. Sci. 2009, 2, 745-758. [CrossRef]

162. Mikkelsen, M.; Jorgensen, M.; Krebs, F.C. The teraton challenge. A review of fixation and transformation of carbon dioxide. Energy Environ. Sci. 2010, 3, 43-81. [CrossRef]

163. Halmann, M. Photoelectrochemical reduction of aqueous carbon dioxide on $p$-type gallium phosphide in liquid junction solar cells. Nature 1978, 275, 115-116. [CrossRef]

164. Inoue, T.; Fujishima, A.; Konishi, S.; Honda, K. Photoelectrocatalytic reduction of carbon dioxide in aqueous suspensions of semiconductor powders. Nature 1979, 277, 637-638. [CrossRef]

165. Harris, L.A.; Wilson, R.H. Semiconductors for Photoelectrolysis. Annu. Rev. Mater. Sci. 1978, 8, 99-137. [CrossRef]

166. Barton, E.E.; Rampulla, D.M.; Bocarsly, A.B. Selective solar-driven reduction of $\mathrm{CO}_{2}$ to methanol using a catalyzed $p$-GaP based photoelectrochemical cell. J. Am. Chem. Soc. 2008, 130, 6342-6344. [CrossRef] [PubMed] 
167. Sakakura, T.; Choi, J.C.; Yasuda, H. Transformation of carbon dioxide. Chem. Rev. 2007, 107, $2365-2387$. [CrossRef] [PubMed]

168. Morris, A.J.; Meyer, G.J.; Fujita, E. Molecular approaches to the photocatalytic reduction of carbon dioxide for solar fuels. Acc. Chem. Res. 2010, 42, 1983-1994. [CrossRef] [PubMed]

169. Takeda, H.; Ishitani, O. Development of efficient photocatalytic systems for $\mathrm{CO}_{2}$ reduction using mononuclear and multinuclear metal complexes based on mechanistic studies. Coord. Chem. Rev. 2010, 254, 346-354. [CrossRef]

170. Nann, T.; Ibrahim, S.K.; Woi, P.M.; Xu, S.; Ziegler, J.; Pickett, C.J. Water splitting by visible light: A nanophotocathode for hydrogen production. Angew. Chem. Int. Ed. 2010, 49, 1574-1577. [CrossRef] [PubMed]

171. Seger, B.; Laursen, A.B.; Vesborg, P.C.K.; Pedersen, T.; Hansen, O.; Dahl, S.; Chorkendorff, I. Hydrogen production using a molybdenum sulfide catalyst on a titanium-protected $n^{+} p$-silicon photocathode. Angew. Chem. Int. Ed. 2012, 51, 9128-9131. [CrossRef] [PubMed]

172. Kumar, B.; Beyler, M.; Kubiak, C.P.; Ott, S. Photoelectrochemical hydrogen generation by an [FeFe] hydrogenase active site mimic at a $p$-type silicon/molecular electrocatalyst junction. Chem. Eur. J. 2012, 18, 1295-1298. [CrossRef] [PubMed]

173. Taniguchi, I.; Aurian-Blajeni, B.; Bockris, J.O.M. The reduction of carbon dioxide at illuminated $p$-type semiconductor electrodes in nonaqueous media. Electrochim. Acta 1984, 29, 923-932. [CrossRef]

174. Hinogami, R.; Nakamura, Y.; Yae, S.; Nakato, Y. An approach to ideal semiconductor electrodes for efficient photoelectrochemical reduction of carbon dioxide by modification with small metal particles. J. Phys. Chem. B 1998, 102, 974-980. [CrossRef]

175. Zheng, J.; Lu, T.; Cotton, T.M.; Chumanov, G. Photoelectrochemical reduction of $\mathrm{CO}_{2}$ mediated with methylviologen at roughened silver electrodes. J. Electroanal. Chem. 2002, 518, 6-12. [CrossRef]

176. Zhou, R.; Guzman, M.I. $\mathrm{CO}_{2}$ Reduction under periodic illumination of ZnS. J. Phys. Chem. C 2014, 118, 11649-11656. [CrossRef]

177. Singh, M.R.; Clark, E.L.; Bell, A.T. Effects of electrolyte, catalyst, and membrane composition and operating conditions on the performance of solar-driven electrochemical reduction of carbon dioxide. Phys. Chem. Chem. Phys. 2015, 17, 18924-18936. [CrossRef] [PubMed]

178. Bocarsly, A.B.; Gibson, Q.D.; Morris, A.J.; L’Esperance, R.P.; Detweiler, Z.M.; Lakkaraju, P.S.; Zeitler, E.L.; Shaw, T.W. Comparative study of imidazole and pyridine catalyzed reduction of carbon dioxide at illuminated iron pyrite electrodes. ACS Catal. 2012, 2, 1684-1692. [CrossRef]

179. Rajeshwar, K.; de Tacconi, N.R.; Ghadimkhani, G.; Chanmanee, W.; Janàky, C. Tailoring copper oxide semiconductor nanorod arrays for photoelectrochemical reduction of carbon dioxide to methanol. Chem. Phys. Chem. 2013, 14, 2251-2259. [CrossRef] [PubMed]

180. Adam, G.; Aslan, F.; Portenkirchner, E.; Stadler, P.; Scharber, M.C.; Sariciftci, N.S. Electrocatalytic reduction of carbon dioxide using sol-gel processed copper indium sulfide (CIS) immobilized on ITO-coated glass electrode. Electrocatalysis 2015, 6, 405-413. [CrossRef]

181. Schrebler, R.; Cury, P.; Herrera, F.; Gomez, H.; Cordova, R. Study of the electrochemical reduction of $\mathrm{CO}_{2}$ on electrodeposited rhenium electrodes in methanol media. J. Electroanal. Chem. 2001, 516, 23-30. [CrossRef]

182. Magesh, G.; Kim, E.S.; Kang, H.J.; Banu, M.; Kim, J.Y.; Kim, J.H.; Lee, J.S. A versatile photoanode-driven photoelectrochemical system for conversion of $\mathrm{CO}_{2}$ to fuels with high faradic efficiencies at low bias potentials. J. Mater. Chem. A 2014, 2, 2044-2049. [CrossRef]

183. Dini, D.; Pryce, M.T.; Schulz, M.; Vos, J.G. Metallosupramolecular assemblies for application as photocatalysts for the production of solar fuels. In Functional Metallosupramolecular Materials; Hardy, J.G., Schacher, F.H., Eds.; Chapter 12; Royal Society of Chemistry: London, UK, 2015; pp. 345-395.

184. Li, L.; Duan, L.; Wen, F.; Li, C.; Wang, M.; Hagfeldt, A.; Sun, L. Visiblelight driven hydrogen production from a photo-active cathode based on a molecular catalyst and organic dye-sensitized $p$-type nanostructured $\mathrm{NiO}$. Chem. Commun. 2012, 48, 988-990. [CrossRef] [PubMed]

(C) 2016 by the authors; licensee MDPI, Basel, Switzerland. This article is an open access article distributed under the terms and conditions of the Creative Commons Attribution (CC-BY) license (http://creativecommons.org/licenses/by/4.0/). 